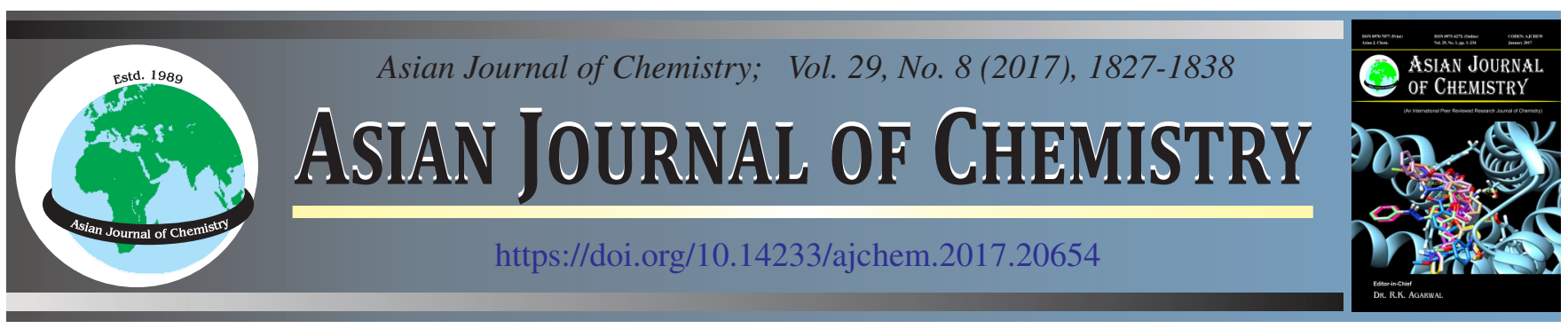

\title{
Thermodynamic Characterization of Metal Dissolution and Inhibitor Adsorption Processes in Mild Steel/New Bipyrazole Derivatives/Hydrochloric Acid System
}

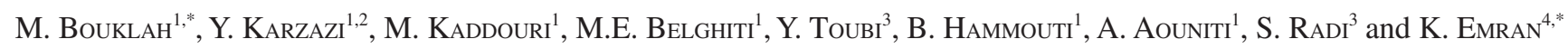

${ }^{1}$ LC2AME, Faculty of Sciences, University Mohammed Premier, B.P. 4808, 60046 Oujda, Morocco

${ }^{2}$ LSIA, ENSAH, University Mohammed Premier, P.O. Box 3, 32003 Sidi Bouafif, ENSA Al Hoceima, Morocco

${ }^{3}$ LCAE, Faculty of Sciences, University Mohammed Premier, B.P. 4808, 60046 Oujda, Morocco

${ }^{4}$ Department of Chemistry, College of Science, Taibah University, B.O. 2455 Al Madina, Saudi Arabia

*Corresponding author: E-mail: boukmmm@yahoo.fr; kabdalsamad@taibahu.edu.sa

\begin{abstract}
Some bipyrazole derivatives $\left\{N, N^{\prime}\right.$-bis-[(3,5-dimethyl-1H-pyrazol-1-yl)methyl]- $N, N^{\prime}$-dimethylethane-1,2-diamine (M1) and $N, N^{\prime}$-bis[(3ethylcarboxylate-5-methyl-1H-pyrazol-1-yl)methyl]- $N, N^{\prime}$-dimethyl ethane-1,2-diamine (M2) $\}$ have been studied as corrosion reduction for mild steel in $1 \mathrm{M} \mathrm{HCl}$ acid. Influence of inhibitors concentration as well as the temperature was investigated using chemical (weight loss) and electrochemical techniques. All the techniques employed are in good agreement. The protection efficiency rise with increasing inhibitors concentration and with rise temperature. Weight loss data used for determining the thermodynamic parameters of dissolution and adsorption processes and the interpretation of the results are given. Adsorption of inhibitor on the carbon steel surface is found to obey the Langmuir adsorption isotherm. Quantum chemical parameters calculation such as the energies of highest occupied molecular orbital ( $\left.\mathrm{E}_{\text {номо }}\right)$ and the lowest unoccupied molecular orbital $\left(\mathrm{E}_{\mathrm{LUMO}}\right)$, energy gap $\left(\Delta \mathrm{E}_{\mathrm{g}}\right)$ between $\mathrm{E}_{\text {Hомо }}$ and $\mathrm{E}_{\mathrm{LUmO}}$, dipole moment $(\mu)$, ionization potential (I), electron affinity (A), global hardness $(\eta)$, global electrophilicity index $(\chi)$, softness $(S)$, back donation energy $\left(\Delta \mathrm{E}_{\text {back donation }}\right)$ total energy and effective atomic charges were calculated. In addition, Monte Carlo (molecular dynamics) simulation was used to simulate the adsorption of bipyrazole derivatives on the iron surface in $1 \mathrm{M} \mathrm{HCl}$ acid.
\end{abstract}

Keywords: Bipyrazole, Corrosion inhibitors, Mild steel, Adsorption, Monte Carlo simulations.

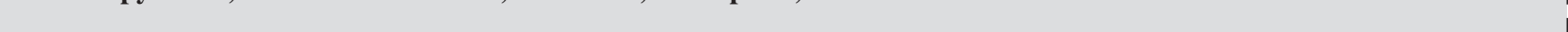

\section{INTRODUCTION}

Aqueous corrosion of many metals and alloys can be retarded by the organic compounds that have demonstrated a great effectiveness in reduction the aqueous corrosion $[1,2]$. Recently, these safe compounds are used as inhibitors because of their good effectiveness. The adsorbtion of these compounds on metallic surfaces in acid solutions is to slow down the cathodic and/or the anodic process of dissolution of the metal. Such effect is obtained by forming a barrier of diffusion or by means of the blockage of the reaction sites. The synthesis of new pyrazolic, bipyrazolic and tripyrazole compounds that include several heteroatoms and several substituents is very easy method. It is well known that pyrazole [3-6], bipyrazole [7-12], tripyrazole [13], triazole [14-20] and tetrazole [21-24] derivative compounds are excellent inhibitors for many metals aggressive solutions. The aim of this work is devoted to study the inhibition characteristics of these compounds for acid corrosion of mild steel using weight loss and electrochemical methods. From experimental data of the studies of inhibition process at different temperatures, thermodynamic parameters are obtained and discussed. The inhibition action of bipyrazole derivatives (Fig. 1) was performed by density functional theory (DFT) and molecular dynamic (MCs) simulation as powerful tools for designing and to correlate molecular structure to electronic calculations.<smiles>CCOC(=O)c1cc(C)n(CN(C)CCN(C)Cn2nc(C(=O)OCC)cc2C)n1</smiles>

M1: $N, N^{\prime}$-bis[(3,5-dimethyl-1H-pyrazol-1-yl)methyl]- $N, N^{\prime}-$ dimethylethane-1,2-diamine; M2: N,N'-bis[(3-ethylcarboxylate-5methyl-1H-pyrazol-1-yl) methyl]- $N, N^{\prime}$-dimethyl ethane-1,2-diamine

Fig. 1. Synthesis of new bipyrazole derivatives 


\section{EXPERIMENTAL}

Specimen and solution preparation: Coupons of commercial sheets of mild steel (containing in wt \%: $0.09 \% \mathrm{P}, 0.38 \%$ $\mathrm{Si}, 0.01 \% \mathrm{Al}, 0.05 \% \mathrm{Mn}, 0.21 \% \mathrm{C}, 0.05 \% \mathrm{~S}$ and the remainder iron) were used for chemical and electrochemical studies. The surface was abraded using emery paper nos. 260, 400 and 1200; they were degreased with AR grade ethanol, acetone and dried at room temperature before use. The test solutions $(1 \mathrm{M} \mathrm{HCl})$ were prepared by dilution of an analytical reagent grade $37 \%$ $\mathrm{HCl}$ with doubly distilled water.

Weight loss measurements: The steel specimens used had a rectangular form $(1.5 \mathrm{~cm} \times 1.5 \mathrm{~cm} \times 0.05 \mathrm{~cm})$, was completely immersed at a double walled glass cell equipped with a thermostat-cooling condenser containing $100 \mathrm{~mL}$ test solution for duplicate experiments weight loss measurements for $6 \mathrm{~h}$ at $308 \mathrm{~K}$. After the weight loss test, the electrode was withdrawn, rinsed with doubly distilled water, washed with ethanol, dried and weighed. The mean value of the weight loss has been recorded. The weight loss was used to calculate the corrosion rate $(\mathrm{W})$ in milligrams per square centimetre per hour $\left(\mathrm{mg} / \mathrm{cm}^{2} \mathrm{~h}\right)$.

Potentiodynamic measurements: Potentiodynamic tests were carried out in three-electrode cylindrical glass cell. The working electrode was a disc of $1 \mathrm{~cm}^{2}$ mild steel. A platine electrode and saturated calomel electrode (SCE) were used as auxiliary and reference electrodes, respectively. The potentiodynamic curves were recorded with a potentiostat type AMEL 550 using a linear sweep generator type AMEL 567 at scan rate of $30 \mathrm{mV} / \mathrm{min}$. Before each cathodic curve, the mild steel electrode was polarized at $800 \mathrm{mV} / \mathrm{SCE}$ for $10 \mathrm{~min}$. For anodic polarization curves, the potential of the working electrode was swept from its open circuit potential value after $30 \mathrm{~min}$ at rest. The test solutions were de-aerated with nitrogen. The nitrogen bubbling was maintained in the solutions during the electrode chemical measurements.

Electrochemical impedance spectroscopy (EIS): The electrochemical system (Tacussel) included a digital potentiostat model Voltalab PGZ 100 computer for EIS measurements in the Nyquist representation. The measurements were carried out at $\mathrm{E}_{\text {corr }}$ after immersion the mild steel in solution without bubbling. Circular surface of working electrode was about 1 $\mathrm{cm}^{2}$. Sine wave voltage $(10 \mathrm{mV})$ peak to peak, at frequencies between $100 \mathrm{kHz}$ and $10 \mathrm{MHz}$ was superimposed on the rest potential after steady-state current after $30 \mathrm{~min}$ of exposure at a given potential. The cell was thermostated at $308 \mathrm{~K}$.

Quantum chemical calculations: Full geometry optimizations of the investigated inhibitors (M1 and M2) have been performed by B3LYP/6-31G** level of theory using Gaussian software 09 [25]. The quantum chemical parameters of M1 and M2 such as the energies of highest occupied molecular orbital $\left(\mathrm{E}_{\text {номо }}\right)$ and the lowest unoccupied molecular orbital $\left(\mathrm{E}_{\mathrm{Lumo}}\right)$, the energy gap $(\Delta \mathrm{E})$ between $\mathrm{E}_{\mathrm{HOmo}}$ and $\mathrm{E}_{\mathrm{Lumo}}$, dipole moment $(\mu)$, ionization potential (I), electron affinity (A), global hardness $(\eta)$, global electrophilicity index $(\chi)$, softness (S) and back donation energy $\left(\Delta \mathrm{E}_{\text {back donation }}\right)$ and total energy charge were used to explicate the electron transfer mechanism between one inhibitor molecule onto the mild steel surface in aqueous solution.
Molecular dynamics (Monte Carlo) simulation measurements: The Monte Carlo (molecular dynamic) simulation (MCs) was carried out using Materials Studio $\mathrm{DMol}^{3}$ code and Adsorption locator commercialized by Accelery Materials Studio version 8.0 [26].

The geometry optimization of investigation molecular structures (one of M1/M2 molecules) are performed with DMol ${ }^{3}$ code. The generalized-gradient approximation (GGA) with the Perdew-Burke-Ernzerhof (PBE) exchange-correlation functional and the double numerical plus polarization (DNP+) basis set was used [27]. The simulation was carried out with iron (111) crystal with a slab of $5 \AA$ in depth with periodic boundary circumstances in order to simulate a representative part of an interface devoid of any arbitrary boundary effects. The simulation was carried out in a simulation box $(30 \AA x$ $30 \AA \times 35 \AA$ ) with periodic boundary conditions in order to simulate a representative part of an interface devoid of any arbitrary boundary effects. After minimizing the Fe (111) surface and one of (M1/M2) molecules in water solvent molecules $\left(30 \mathrm{H}_{2} \mathrm{O}\right)$, the corrosion system will be built by layer builder to place the (M1/M2) molecules on the iron (111) surface and the adsorption of bipyrazole derivatives on the iron (111) surface were simulated using the COMPASS (condensed phase optimized molecular potentials for atomistic simulation studies) force field [28]. The lower energies adsorption centers are identified by carrying out a MCs search of the configurationally space for (M1 \& M2)/Fe (111) system [29,30]. All calculations related to the single and neutral form of bipyrazole derivatives and iron (111) surface obtained by $\mathrm{Dmol}^{3}$ code and adsorption locator module are done in 30 molecules of water.

\section{RESULTS AND DISCUSSION}

Weight loss measurements: Table-1 collects the corrosion rate of mild steel in $1 \mathrm{M} \mathrm{HCl}\left(\mathrm{W}_{\text {corr }}^{0}\right)$ and at various amount of $\mathrm{M} 1$ and M2 ( $\left.\mathrm{W}_{\text {corr }}\right)$ determined at $308 \mathrm{~K}$ after $1 \mathrm{~h}$ of immersion rate and inhibition efficiencies $\mathrm{E} \%$, determined by eqn. 1:

$$
\mathrm{E}(\%)=\left(\frac{\mathrm{W}_{\text {corr }}-\mathrm{W}_{\text {corr'inh }}}{\mathrm{W}_{\text {corr }}}\right) \times 100
$$

where $\mathrm{W}_{\text {corr }}$ and $\mathrm{W}^{\circ}$ corr are the corrosion rates of mild steel with and without bipyrazole derivatives.

\section{TABLE-1}

GRAVIMETRIC RESULTS OF MILD STEEL IN $1 \mathrm{M} \mathrm{HCl} \mathrm{WITH} \mathrm{AND} \mathrm{WITHOUT} \mathrm{THE} \mathrm{BIPYRAZOLE}$ DERIVATIVES AT VARIOUS CONCENTRATIONS

\begin{tabular}{ccccc}
\hline Inhibitors & $\mathrm{C}(\mathrm{M})$ & $\mathrm{W}\left(\mathrm{mg} / \mathrm{cm}^{2} \mathrm{~h}\right)$ & $\mathrm{E}_{\mathrm{w}}(\%)$ & $\theta$ \\
\hline Blank & 1 & $1.855 \times 10^{-3}$ & - & - \\
\hline \multirow{4}{*}{ M1 } & $10^{-3}$ & $2.550 \times 10^{-4}$ & 87.00 & 0.8700 \\
& $5 \times 10^{-4}$ & $3.880 \times 10^{-4}$ & 79.08 & 0.7908 \\
& $10^{-4}$ & $1.200 \times 10^{-3}$ & 35.00 & 0.3500 \\
& $5 \times 10^{-5}$ & $1.285 \times 10^{-3}$ & 31.00 & 0.3100 \\
& $10^{-5}$ & $1.651 \times 10^{-3}$ & 11.00 & 0.1100 \\
& $10^{-6}$ & $1.720 \times 10^{-3}$ & 08.00 & 0.0800 \\
\hline \multirow{4}{*}{ 2 } & $10^{-3}$ & $8.830 \times 10^{-5}$ & 95.23 & 0.9523 \\
& $5 \times 10^{-4}$ & $1.782 \times 10^{-4}$ & 90.40 & 0.9040 \\
& $10^{-4}$ & $2.110 \times 10^{-4}$ & 88.62 & 0.8862 \\
& $5 \times 10^{-5}$ & $2.520 \times 10^{-4}$ & 86.41 & 0.8641 \\
& $10^{-5}$ & $4.854 \times 10^{-4}$ & 73.83 & 0.7383 \\
& $10^{-6}$ & $7.526 \times 10^{-4}$ & 59.42 & 0.5942 \\
\hline
\end{tabular}


The presence of compounds decreases the corrosion rate in $\mathrm{HCl}$ solution. The inhibitory effect increases with increasing concentration of bipyrazoles derivatives. The inhibition efficiency $(\mathrm{E} \%)$ reaches a maximum of $95 \%$ at $10^{-3} \mathrm{M}$ for M2. The presence of the ester group in M2 which has mesomer effect, reinforce the effectiveness of it compared to inductive effect by methyl in M1. The interaction between $\pi$-electrons of the pyrazole rings and heteroatom with positively charged steel surface increase the protective properties of these compounds [31,32]. Generally (M1 and M2) compounds can be defined as good inhibitors of steel corrosion in $1 \mathrm{M} \mathrm{HCl}$ solution.

Electrochemecal polarization measurements: The inhibition efficiency (E \%) from polarization method was determines using eqn. 2 :

$$
E_{I}=100 \times\left(1-\frac{i_{\text {corr }}}{i_{\text {corr }}^{o}}\right)
$$

where $\mathrm{i}_{\text {corr }}^{\circ}$ and $\mathrm{i}_{\text {corr }}$ are the uninhibited and inhibited corrosion current densities, respectively. Polarization behaviour of mild steel in $1 \mathrm{M} \mathrm{HCl}$ is shown in Fig. 2, in the presence and absence of inhibitors. The values of corrosion current $\left(i_{\text {corr }}\right)$, corrosion potential $\left(E_{\text {corr }}\right)$, cathodic Tafel slope $\left(\beta_{c}\right)$ and inhibition efficiency (E \%), are shown in Table-2.

TABLE-2

POLARIZATION PARAMETERS FOR STEEL IN ACID AT DIFFERENT CONTENTS OF M1 AND M2 AT $308 \mathrm{~K}$

\begin{tabular}{cccccc}
\hline Inhibitors & $\mathrm{C}(\mathrm{M})$ & $\begin{array}{c}\mathrm{E}_{\text {corr }} \\
(\mathrm{mv} / \mathrm{SCE})\end{array}$ & $\begin{array}{c}\mathrm{i}_{\text {corr }} \\
\left(\mathrm{mA} / \mathrm{cm}^{2}\right)\end{array}$ & $\begin{array}{c}\beta_{\mathrm{c}} \\
(\mathrm{mV} / \mathrm{dec})\end{array}$ & $\mathrm{E}_{\mathrm{I}}(\%)$ \\
\hline $\mathrm{HCl}$ & $1 \mathrm{M}$ & -478.0 & 0.5735 & -152.0 & - \\
\hline \multirow{3}{*}{$\mathrm{M} 1$} & $10^{-6}$ & -469.7 & 0.4744 & -145.2 & 17.30 \\
& $10^{-5}$ & -476.7 & 0.3797 & -201.2 & 33.80 \\
& $10^{-4}$ & -470.5 & 0.2617 & -128.7 & 54.36 \\
& $10^{-3}$ & -461.5 & 0.0754 & -166.5 & 87.00 \\
\hline \multirow{3}{*}{$\mathrm{M} 2$} & $10^{-6}$ & -465.6 & 0.1430 & -123.0 & 75.00 \\
& $10^{-5}$ & -466.9 & 0.0463 & -192.9 & 92.00 \\
& $10^{-4}$ & -480.9 & 0.0375 & -178.3 & 93.00 \\
& $10^{-3}$ & -454.5 & 0.0256 & -173.1 & 95.53 \\
\hline
\end{tabular}

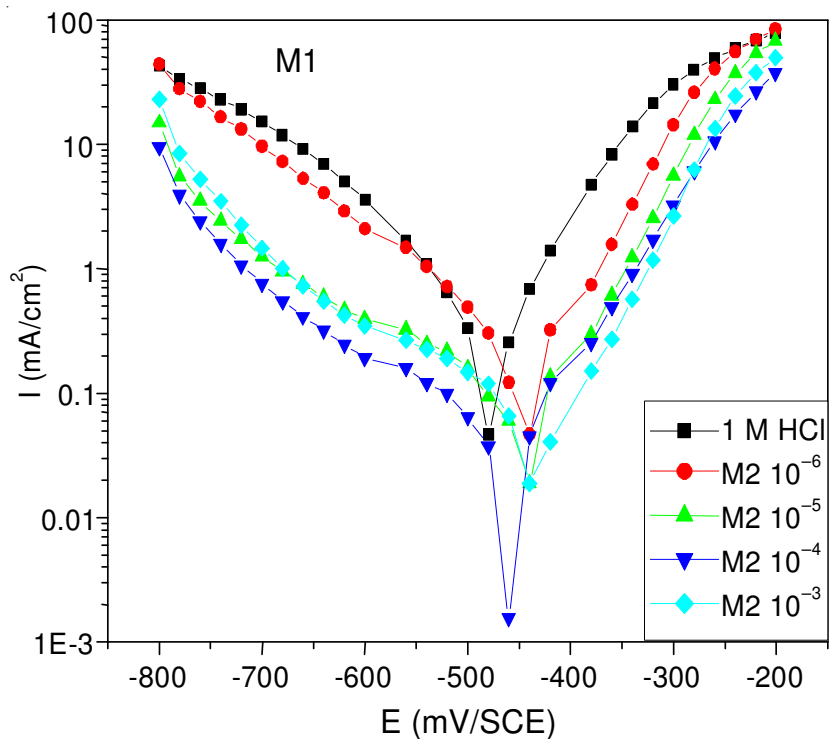

Fig. 2 and Table- 2 show that the presence of M1 and M2 decreases $i_{\text {corr }}$ values. The reduction is more pronounced with the increase of the bipyrazole derivatives concentration. The cathodic curves indicate that the mechanism of hydrogen reduction is activation control. In addition, the mechanism of $\mathrm{H}^{+}$reduction is not modified with the M1 and M2 presence. Corrosion potential $\mathrm{E}_{\text {corr }}$ shifts have no definite trend, which indicate that these bipyrazoles act as mixed inhibitors by simple blocking the available active sits on the surface. At $10^{-3} \mathrm{M}$ of M1 and M2, the inhibition efficiency reaches $87 \%$ and $95.5 \%$ respectively. This phenomenon is interpreted by the adsorption of the bipyrazoles molecules on mild steel surface leading to the increment of the surface coverage $\theta$ determine by $\mathrm{E} \% /$ 100. The inhibition efficiency (E \%) increases with test compound concentration.

Electrochemical impedance measurements: Nyquist plots for mild steel in Fig. 3 in $1 \mathrm{M} \mathrm{HCl}$ consist of one capacitive loop with one time constant in absence and presence of different concentrations of bipyrazole compounds M1 and M2.

The interpretation of Nyquist spectra in Fig. 3 allow to determine the electrochemical parameters of the steel electrode such as the charge transfer resistance values $\left(R_{c t}\right)$ and constant phase element (CPE). These parameters acquire information about the corrosion process and mechanism. The inhibition efficiency $(\mathrm{E} \%)$ is calculated using charge transfer resistance from the following equation $[33,34]$ :

$$
E(\%)=\frac{\left(R_{t / i n h}-R_{t}\right)}{R_{t / i n h}} \times 100
$$

where $R_{c t}$ and $R_{c t i n h}$ are the charge transfer resistance values in absence and presence of inhibitor for mild steel in $1 \mathrm{M} \mathrm{HCl}$, respectively. Table- 3 shows that these compounds obviously slow down the corrosion of mild steel in $1 \mathrm{M} \mathrm{HCl}$ by rising the $\mathrm{R}_{\mathrm{ct}}$ and constant phase element values decrease. The inhibition efficiency rises by increasing the M1 and M2 concentration. The decrease in the constant phase element values may be explained by the modification of the structure of double

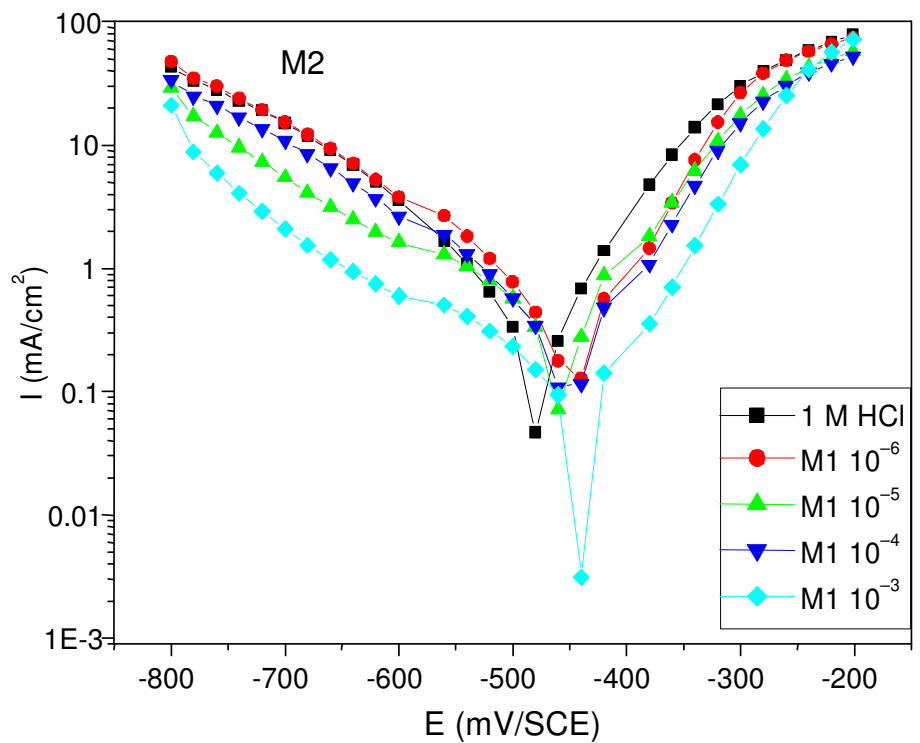

Fig. 2. Typical polarization curves of steel in $1 \mathrm{M} \mathrm{HCl}$ for various concen-trations of $\mathrm{M} 1$ and $\mathrm{M} 2$ 

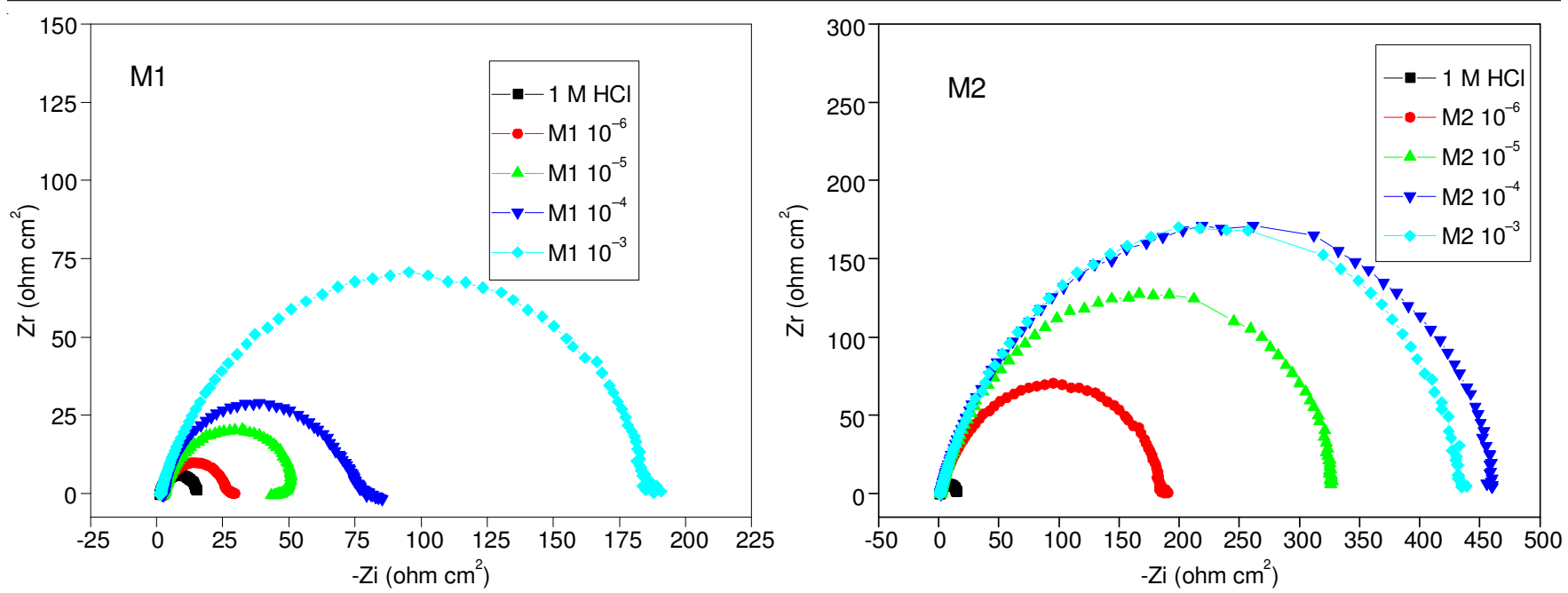

Fig. 3. Nyquist diagrams for steel in $1 \mathrm{M} \mathrm{HCl}$ with different concentrations of $\mathrm{M} 1$ and M2

\begin{tabular}{|c|c|c|c|c|c|c|}
\hline \multicolumn{7}{|c|}{$\begin{array}{c}\text { TABLE-3 } \\
\text { IMPEDANCE DATA OF MILD STEEL IN } 1 \mathrm{M} \text { HCI IN ABSENCE } \\
\text { AND PRESENCE OF DIFFERENT CONCENTRATIONS FROM } \\
\text { BIPYRAZOLE ACID DERIVATIVES }\end{array}$} \\
\hline Inhibitors & $\mathrm{C}(\mathrm{M})$ & $\begin{array}{c}\mathrm{R}_{\mathrm{s}}(\Omega \\
\left.\mathrm{cm}^{2}\right)\end{array}$ & $\begin{array}{c}\mathrm{R}_{\mathrm{t}}(\Omega \\
\left.\mathrm{cm}^{2}\right)\end{array}$ & $\begin{array}{l}\mathrm{F}_{\max } \\
(\mathrm{Hz})\end{array}$ & $\begin{array}{c}\mathrm{CPE} \\
(\mu \mathrm{F} \\
\left.\mathrm{cm}^{-2}\right)\end{array}$ & $\mathrm{E}(\%)$ \\
\hline \multirow{5}{*}{ M1 } & $1 \mathrm{M} \mathrm{HCl}$ & 2.00 & 20 & 113.70 & 70.00 & - \\
\hline & $10^{-6} \mathrm{M}$ & 1.95 & 25 & 98.70 & 64.50 & 20.00 \\
\hline & $10^{-5} \mathrm{M}$ & 1.95 & 60 & 44.14 & 60.10 & 66.66 \\
\hline & $10^{-4} \mathrm{M}$ & 1.93 & 75 & 38.44 & 55.20 & 73.33 \\
\hline & $10^{-3} \mathrm{M}$ & 1.92 & 190 & 15.86 & 52.80 & 89.47 \\
\hline \multirow{4}{*}{ M2 } & $10^{-6} \mathrm{M}$ & 1.93 & 200 & 12.89 & 61.70 & 90.00 \\
\hline & $10^{-5} \mathrm{M}$ & 1.87 & 350 & 7.70 & 59.07 & 94.28 \\
\hline & $10^{-4} \mathrm{M}$ & 1.90 & 460 & 6.03 & 57.30 & 95.56 \\
\hline & $10^{-3} \mathrm{M}$ & 1.82 & 450 & 12.54 & 56.40 & 95.55 \\
\hline
\end{tabular}

layer due to the adsorption of the inhibitor on the steel surface [35] expressed in the Helmholtz model by:

$$
\mathrm{C}_{\mathrm{dl}}=\frac{\varepsilon_{0} \cdot \varepsilon}{\delta} \mathrm{S}
$$

where $\delta$ is the thickness of electrical double layer, $S$ is the surface of the electrode, $\varepsilon_{0}$ is the permittivity of vacuum and $\varepsilon$ is the medium dielectric constant.

The adsorption of these compounds on mild steel surface can occur either directly on the basis of interaction between the $\pi$ electrons (donor) and the vacant $d$-orbitals of steel surface atoms (acceptor). Also by interaction of them with already adsorbed chloride ions on the surface [36,37].

Adsorption might also occur in the positively charged part (cationic form) of the bipyrazole compounds oriented toward negative ends of the halide metal dipoles. This fact supports the observed reducing in $\mathrm{C}_{\mathrm{dl}}$ values in the EIS measurement (Table-3). It is clear that compound M2 which include ester group is the best inhibitor. This group has powerful mesomer effect, which facilitate the delocalization of electron. The impedance response of mild steel in $1 \mathrm{M} \mathrm{HCl}$ has significantly changed after the addition of bipyrazole derivatives in the corrosive system.

Equivalent circuit of the electrical double layer shown in Fig. 4 has been used to model the mild steel/HCl interface. Nyquist spectra in Fig. 3, are depressed and not perfect semi-

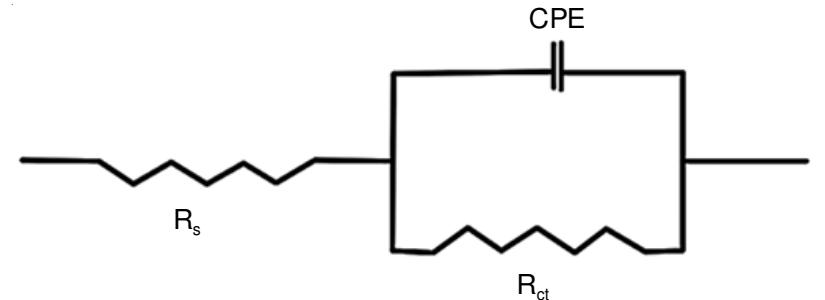

Fig. 4. Suggested equivalent circuit model for the studied system

circles into the $\mathrm{Zr}$ as a result of the roughness and/or homogeneities of the metal surface [38,39]. This type of phenomena is call "the dispersing effect" [40,41]. The result of this dispersing effect is due to the deferent of the sepsis on the metal/ solution sides. On the metal side, electrons control the charge distribution whereas on the solution side it is controlled by ions which are much larger than electrons. So, quite large volume of equivalent ions to the charge will occupy the solution side of the double layer [38].

Effect of temperature: Temperature influence on the efficiency of M1 and M2 was studied in $1 \mathrm{M} \mathrm{HCl} \mathrm{using} \mathrm{weight-}$ loss measurements in the temperature range $318-348 \mathrm{~K}$ at various M1 and M2 concentrations during $1 \mathrm{~h}$ of immersion. For blank solution, the rising of corrosion rate is more pronounced with the rise of temperature (Table-4). In the addition of the bipyrazole compounds, $\mathrm{W}_{\text {corr }}$ is highly reduced. The $\mathrm{E} \%$ depends on the temperature and reduces with the rise of temperature. This can be explained by physical adsorption mode where the strength of the adsorption process decreased at elevated temperature.

Arrhenius eqn. 5 and its alternative formulation called transition state eqn. 6 were used to calculate the energy $E_{a}$, the entropy $\Delta \mathrm{S}^{\circ}$ and the enthalpy $\Delta \mathrm{H}^{\circ}$ of activation:

$$
\begin{gathered}
\mathrm{W}=\mathrm{k} \exp \left(-\frac{\mathrm{E}_{\mathrm{a}}}{\mathrm{RT}}\right) \\
\mathrm{W}=\frac{\mathrm{RT}}{\mathrm{Nh}} \exp \left(\frac{\Delta \mathrm{S}_{\mathrm{a}}^{\mathrm{o}}}{\mathrm{R}}\right) \exp \left(-\frac{\Delta \mathrm{H}_{\mathrm{a}}^{\mathrm{o}}}{\mathrm{RT}}\right)
\end{gathered}
$$

where $\mathrm{T}$ is the absolute temperature. $\mathrm{K}$ is a constant and $\mathrm{R}$ is the universal gas constant. $\mathrm{h}$ is Plank's constant and $\mathrm{N}$ is Avogadro's number. 


\begin{tabular}{|c|c|c|c|c|c|c|c|c|c|c|c|}
\hline & EFFE & $\begin{array}{l}\text { [ OF TEMP } \\
\text { AND M } 2 \text { A }\end{array}$ & $\begin{array}{l}\text { ATURE ON } \\
0^{-3} \text { TO } 10^{-6} \mathrm{~N}\end{array}$ & $\begin{array}{l}\mathrm{HECOR} \\
\text { AND TI }\end{array}$ & $\begin{array}{r}\text { TA } \\
\text { SION R } \\
\text { CORRE }\end{array}$ & $\begin{array}{l}\text { E-4 } \\
\text { TE OF ST } \\
\text { ONDING }\end{array}$ & $\begin{array}{l}\text { L IN } 1 \\
\text { DRROS }\end{array}$ & $\begin{array}{l}\mathrm{HCl}\left(\mathrm{W}_{0}\right) \mathrm{W} \\
\mathrm{N} \text { INHIBITI }\end{array}$ & $\begin{array}{l}\text { ГHOUT AND } \\
\text { N EFFICIEN }\end{array}$ & ${ }_{Y}$ & \\
\hline Inhibitor & $\mathrm{T}(\mathrm{K})$ & $\mathrm{C}(\mathrm{M})$ & $\begin{array}{c}\mathrm{W} \\
\left(\mathrm{mg} / \mathrm{cm}^{2} \mathrm{~h}\right)\end{array}$ & $\mathrm{E}(\%)$ & $\theta$ & Inhibitor & $\mathrm{T}(\mathrm{K})$ & $\mathrm{C}(\mathrm{M})$ & $\begin{array}{c}\mathrm{W} \\
\left(\mathrm{mg} / \mathrm{cm}^{2} \mathrm{~h}\right)\end{array}$ & $\mathrm{E}(\%)$ & $\theta$ \\
\hline \multirow{20}{*}{ M1 } & \multirow{5}{*}{318} & Blank $1 \mathrm{M}$ & 1.908 & - & - & \multirow{20}{*}{ M2 } & \multirow{5}{*}{318} & Blank $1 \mathrm{M}$ & 1.908 & - & - \\
\hline & & $10^{-6}$ & 1.602 & 16.00 & 0.1600 & & & $10^{-6}$ & 1.050 & 45.00 & 0.4500 \\
\hline & & $10^{-5}$ & 1.526 & 20.00 & 0.2000 & & & $10^{-5}$ & 0.7250 & 62.00 & 0.6200 \\
\hline & & $10^{-4}$ & 1.135 & 40.50 & 0.4050 & & & $10^{-4}$ & 0.4357 & 77.16 & 0.7716 \\
\hline & & $10^{-3}$ & 0.2671 & 86.00 & 0.8600 & & & $10^{-3}$ & 0.243 & 87.26 & 0.8726 \\
\hline & \multirow{5}{*}{328} & Blank $1 \mathrm{M}$ & 2.092 & - & - & & \multirow{5}{*}{328} & Blank $1 \mathrm{M}$ & 2.092 & - & - \\
\hline & & $10^{-6}$ & 1.882 & 10.00 & 0.1000 & & & $10^{-6}$ & 1.360 & 35.00 & 0.3500 \\
\hline & & $10^{-5}$ & 1.757 & 16.00 & 0.1600 & & & $10^{-5}$ & 0.9523 & 54.00 & 0.5400 \\
\hline & & $10^{-4}$ & 1.360 & 35.00 & 0.3500 & & & $10^{-4}$ & 0.6440 & 69.20 & 0.6920 \\
\hline & & $10^{-3}$ & 0.4602 & 78.00 & 0.7800 & & & $10^{-3}$ & 0.3240 & 84.51 & 0.8451 \\
\hline & \multirow{5}{*}{338} & Blank $1 \mathrm{M}$ & 3.890 & - & - & & \multirow{5}{*}{338} & Blank $1 \mathrm{M}$ & 3.890 & - & - \\
\hline & & $10^{-6}$ & 3.5729 & 08.15 & 0.0815 & & & $10^{-6}$ & 2.746 & 31.00 & 0.3100 \\
\hline & & $10^{-5}$ & 3.4366 & 11.65 & 0.1165 & & & $10^{-5}$ & 2.145 & 46.10 & 0.4610 \\
\hline & & $10^{-4}$ & 3.112 & 23.00 & 0.2300 & & & $10^{-4}$ & 1.452 & 63.50 & 0.6350 \\
\hline & & $10^{-3}$ & 1.280 & 67.12 & 0.6712 & & & $10^{-3}$ & 1.120 & 71.21 & 0.7121 \\
\hline & \multirow{5}{*}{348} & Blank $1 \mathrm{M}$ & 8.744 & - & - & & \multirow{5}{*}{348} & Blank $1 \mathrm{M}$ & 8.744 & - & - \\
\hline & & $10^{-6}$ & 8.1124 & 07.22 & 0.0722 & & & $10^{-6}$ & 6.808 & 22.13 & 0.2213 \\
\hline & & $10^{-5}$ & 7.3323 & 16.14 & 0.1614 & & & $10^{-5}$ & 5.819 & 33.45 & 0.3345 \\
\hline & & $10^{-4}$ & 7.257 & 17.00 & 0.1700 & & & $10^{-4}$ & 4.284 & 51.00 & 0.5100 \\
\hline & & $10^{-3}$ & 3.733 & 57.31 & 0.5731 & & & $10^{-3}$ & 3.497 & 60.00 & 0.6000 \\
\hline
\end{tabular}
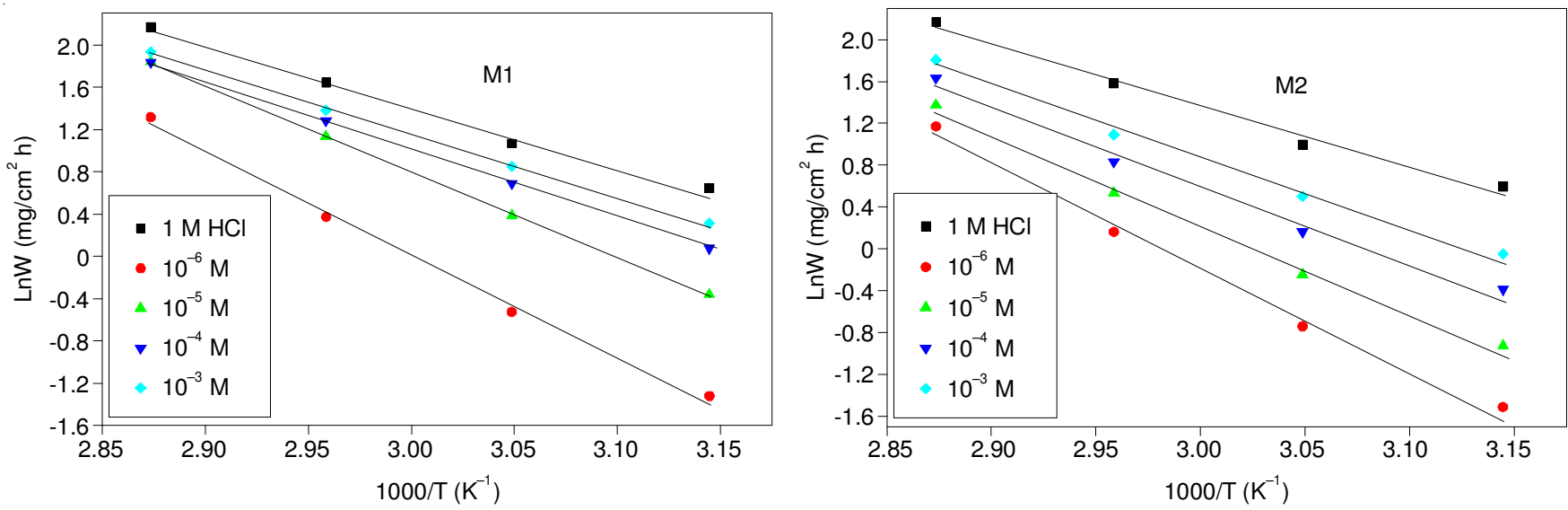

Fig. 5. Arrhenius plots for steel in $1 \mathrm{M} \mathrm{HCl}$ in the absence and presence of $\mathrm{M} 1$ and M2
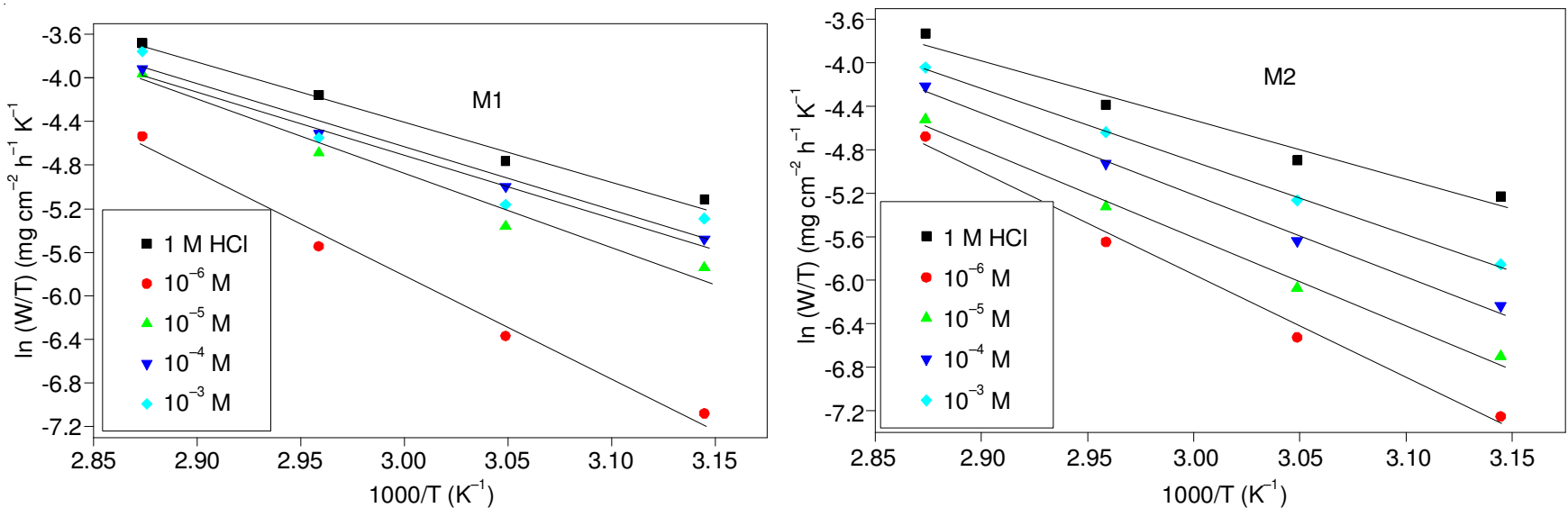

Fig. 6. Relation between $\log (\mathrm{W} / \mathrm{T})$ vs. $1 / \mathrm{T}$ for steel at different concentrations of M1 and M2

From this relation in Fig. 6, the values of $\Delta \mathrm{H}^{\circ}$ and $\Delta \mathrm{S}^{\circ}$ can be calculated. The decrease of M1 and M2 efficiencies with temperature rise leads to higher values of $\mathrm{E}_{\mathrm{a}}$ (Table 5), when compared to that in a blank acid. The higher values of $E_{a}$ are interpreted as an indication of electrostatic character of the inhibitor's adsorption [42]. Data in Table-5 provide that the 


\begin{tabular}{|c|c|c|c|c|c|}
\hline & \multicolumn{5}{|c|}{$\begin{array}{c}\text { TABLE-5 } \\
\text { VALUES OF ACTIVATION PARAMETERS } \\
\mathrm{E}_{\mathrm{a}} \cdot \Delta \mathrm{H}_{\mathrm{a}}^{0} \text { AND } \Delta \mathrm{S}_{\mathrm{a}}^{0} \text { FOR MILD STEEL IN } 1 \mathrm{M} \\
\text { HCI IN THE ABSENCE AND THE PRESENCE OF } \\
\text { DIFFERENT CONCENTRATIONS OF M1 AND M2 }\end{array}$} \\
\hline & $\mathrm{C}(\mathrm{M})$ & $\begin{array}{l}\mathrm{E}_{\mathrm{a}}(\mathrm{kJ} \\
\left.\mathrm{mol}^{-1}\right)\end{array}$ & $\begin{array}{c}\Delta \mathrm{H}_{\mathrm{a}}^{0} \\
\left(\mathrm{~kJ} \mathrm{~mol}^{-1}\right)\end{array}$ & $\begin{array}{c}\Delta \mathrm{S}_{\mathrm{a}}^{0}(\mathrm{~J} \\
\left.\mathrm{mol}^{-1} \mathrm{~K}^{-1}\right)\end{array}$ & $\begin{array}{c}\mathrm{E}_{\mathrm{a}}-\Delta \mathrm{H}_{\mathrm{a}}^{0} \\
\left(\mathrm{~kJ} \mathrm{~mol}^{-1}\right)\end{array}$ \\
\hline Blank & Blank & 47.33 & 44.54 & -101.87 & 2.79 \\
\hline \multirow{4}{*}{ M1 } & $10^{-6} \mathrm{M}$ & 81.92 & 79.16 & -09.10 & 2.76 \\
\hline & $10^{-5} \mathrm{M}$ & 58.46 & 54.20 & -71.15 & 4.26 \\
\hline & $10^{-4} \mathrm{M}$ & 49.16 & 46.39 & -97.74 & 2.77 \\
\hline & $10^{-3} \mathrm{M}$ & 48.27 & 45.54 & -93.75 & 2.73 \\
\hline \multirow{4}{*}{ M2 } & $10^{-6} \mathrm{M}$ & 84.55 & 81.79 & -02.55 & 2.76 \\
\hline & $10^{-5} \mathrm{M}$ & 70.20 & 67.43 & -42.11 & 2.77 \\
\hline & $10^{-4} \mathrm{M}$ & 67.43 & 61.84 & -55.58 & 5.59 \\
\hline & $10^{-3} \mathrm{M}$ & 46.77 & 54.94 & -73.98 & 8.17 \\
\hline
\end{tabular}

dissolution reaction is an exothermic process (positive sign of $\Delta \mathrm{H}^{\circ}$ ) [43]. The more positively entropy $\Delta \mathrm{S}^{\circ}$ positively reflects the formation of an ordered stable layer of the inhibitor on the steel surface [44].

Adsorption isotherm: Adsorption isotherms give the basic information of the interaction between the inhibitor and the metal. The surface coverage $\theta$ of the metal surface by the adsorbed inhibitor was calculated using the eqn. 7:

$$
\theta=\frac{\mathrm{W}_{\text {corr }}-\mathrm{W}_{\text {corr (inh) }}}{\mathrm{W}_{\text {corr }}}
$$

By far the best fit is obtained with Langmuir isotherm. According to this isotherm $\theta$ is related to concentration inhibitor C via

$$
\begin{gathered}
\frac{\mathrm{C}}{\theta}=\frac{1}{\mathrm{~K}}+\mathrm{C} \\
\text { with } \quad \mathrm{K}=\frac{1}{55.5} \exp \left(\frac{-\Delta \mathrm{G}_{\mathrm{ads}}^{\mathrm{o}}}{\mathrm{RT}}\right)
\end{gathered}
$$

where $\mathrm{K}$ is the adsorptive equilibrium constant and $\Delta \mathrm{G}_{\text {ads }}^{\circ}$ is the free energy of adsorption.

The straight lines of the plot $\theta / \mathrm{C}$ versus $\mathrm{C}$ with slope equal or nearly equal to 1.00 for 318. 328. 338 and $348 \mathrm{~K}$ (Fig. 7).

The values of $K$ were used to estimate $\Delta \mathrm{G}^{\circ}$ ads values at different temperatures according to eqn. 9 and show spontaneous adsorption process [45-49]. The high values of $\Delta \mathrm{G}^{\circ}$ ads obtained in presence of bipyrazole derivatives in $1 \mathrm{M} \mathrm{HCl} \mathrm{reveal}$ chemisorption of these compounds on the metal [50-54].

The $\Delta \mathrm{H}^{\circ}$ ads and $\Delta \mathrm{S}^{\circ}$ ads for the adsorption of M1 and M2 on mild steel can be calculated from eqn. 10:

$$
\Delta \mathrm{G}_{\mathrm{ads}}^{\mathrm{o}}=\Delta \mathrm{H}_{\mathrm{ads}}^{\mathrm{o}}-\mathrm{T} \Delta \mathrm{S}_{\mathrm{ads}}^{\mathrm{o}}
$$

where $\Delta \mathrm{H}^{\circ}$ ads and $\Delta \mathrm{S}^{\circ}$ ads are the variation of enthalpy and entropy of the adsorption process, respectively. The calculated values from Fig. 8 are depicted in Table-6. The negative sign of $\Delta \mathrm{H}^{\circ}$ ads and more positive $\Delta \mathrm{S}^{\circ}{ }_{\text {ads }}$ indicate an exothermic process and an increase in disordering takes places in going from reactants to the metal adsorbed species reaction complex, respectively [55].

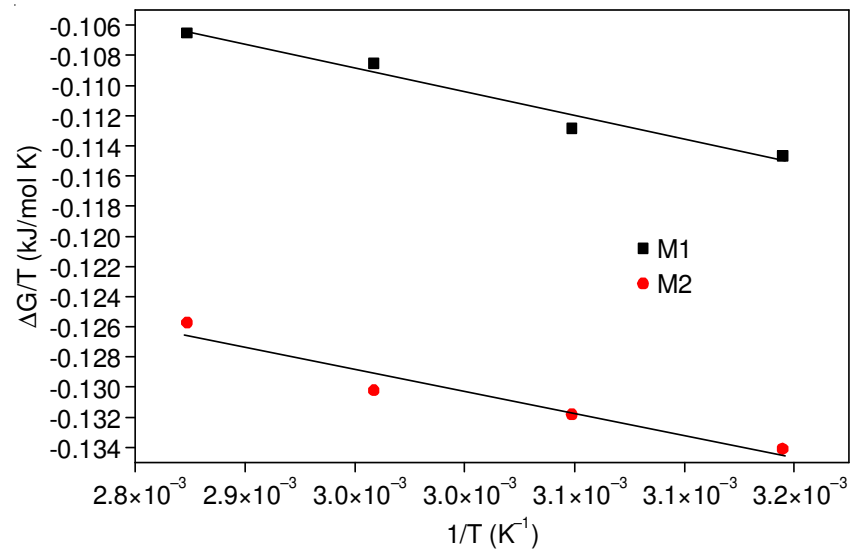

Fig. 8. Relationship between $\Delta \mathrm{G}_{\text {ads }}^{\circ}$ and $\mathrm{T}$

$\Delta \mathrm{H}^{\circ}{ }_{\text {ads }}$ can also be calculated according to the van't Hoff equation (eqn. 11):

$$
\ln \mathrm{K}=\frac{-\Delta \mathrm{H}_{\mathrm{ads}}^{\mathrm{o}}}{\mathrm{RT}}+\text { constant }
$$

Calculated negative $\Delta \mathrm{H}^{\circ}$ ads using the van't Hoff equation (Fig. 9) confirming the exothermic conduct of the adsorption process on the steel surface. Table-7 shows good agreement between the values of $\Delta \mathrm{H}^{\circ}$ ads obtained by the two methods. Bipyrazole derivatives (M1 and M2) may adsorb on a metal surface in the form of a neutral molecule via the chemisorption mechanism [56]. This type of adsorption involving sharing of electrons between the nitrogen atoms and iron. Also. there are
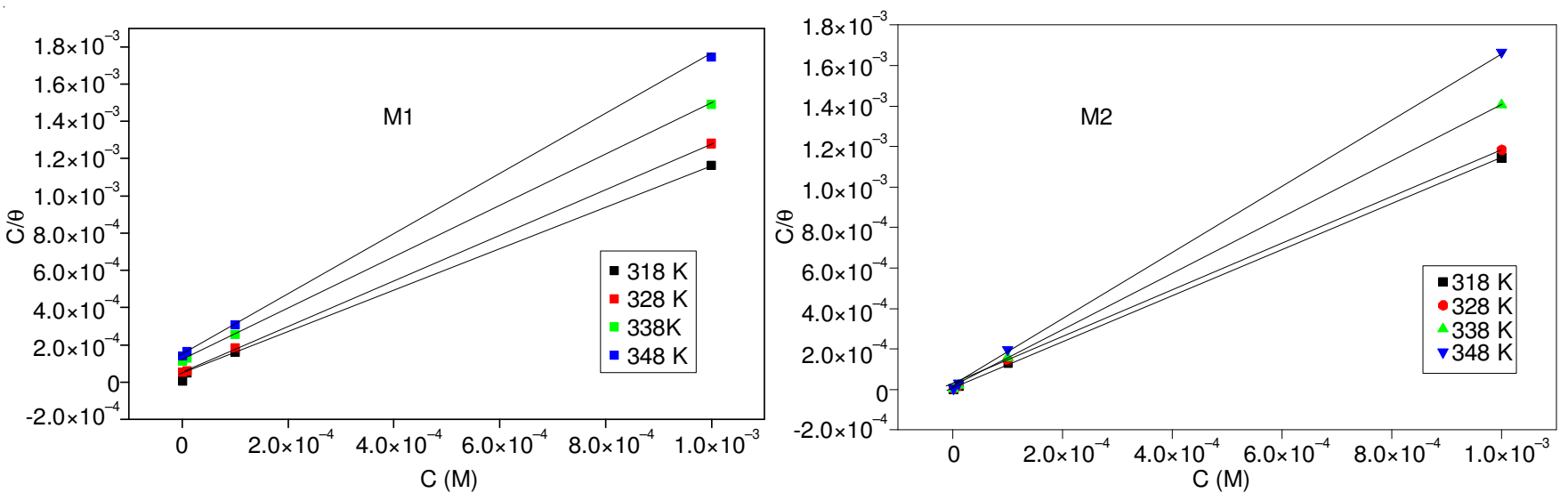

Fig. 7. Langmuir adsorption plots for carbon steel in $1 \mathrm{M} \mathrm{HCl}$ containing different concentrations of inhibitor at different temperatures 
TABLE-6

THERMODYNAMIC PARAMETERS FOR SOME INHIBITORS STUDIED AT CARBON STEEL SURFACE IN $1 \mathrm{M} H C l$

\begin{tabular}{|c|c|c|c|c|c|c|c|}
\hline Inhibitor & $\mathrm{T}(\mathrm{K})$ & A & $\mathrm{K}$ & B & $\Delta \mathrm{G}_{\text {ads }}^{\circ}\left(\mathrm{kJ} \mathrm{mol}^{-1}\right)$ & $\Delta \mathrm{H}^{\circ}{ }_{\text {ads }}\left(\mathrm{kJ} \mathrm{mol}^{-1}\right)$ & $\Delta \mathrm{S}_{\text {ads }}^{\circ}\left(\mathrm{J} \mathrm{mol}^{-1} \mathrm{~K}^{-1}\right)$ \\
\hline \multirow{4}{*}{ M1 } & 318 & $5.7340 \times 10^{-5}$ & 17439.83 & 1.11 & -36.46 & \multirow[t]{4}{*}{-31.73} & 14.87 \\
\hline & 328 & $7.1283 \times 10^{-5}$ & 14028.59 & 1.21 & -37.01 & & 16.09 \\
\hline & 338 & $1.2000 \times 10^{-4}$ & 8333.33 & 1.38 & -36.68 & & 14.64 \\
\hline & 348 & $1.5270 \times 10^{-4}$ & 6548.78 & 1.61 & -37.07 & & 15.34 \\
\hline \multirow{4}{*}{ M2 } & 318 & $6.8500 \times 10^{-6}$ & 145985.4 & 1.13 & -35.99 & \multirow[t]{4}{*}{-29.46} & 20.53 \\
\hline & 328 & $1.1369 \times 10^{-5}$ & 87958.84 & 1.17 & -42.02 & & 38.29 \\
\hline & 338 & $8.8400 \times 10^{-6}$ & 113122.17 & 1.39 & -44.01 & & 43.04 \\
\hline & 348 & $1.5157 \times 10^{-5}$ & 65976.11 & 1.65 & -43.75 & & 41.06 \\
\hline
\end{tabular}

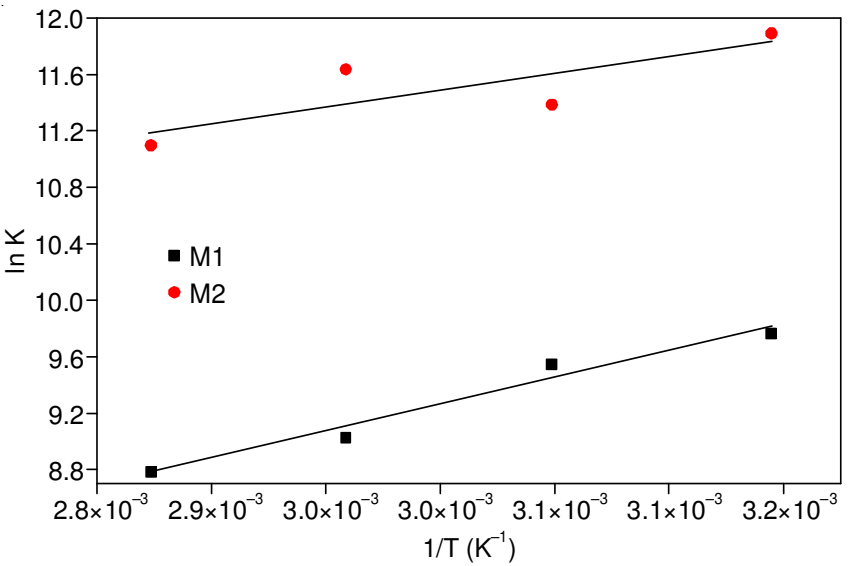

Fig. 9. Relationship between $\ln \mathrm{K}$ and $1 / \mathrm{T}$

\begin{tabular}{ccc}
\multicolumn{3}{c}{ TABLE-7 } \\
\multicolumn{3}{c}{$\begin{array}{c}\text { VAN'T HOFF, GIBBS-HELMHOLTZ AND } \\
\text { THERMODYNAMIC PARAMETERS }\end{array}$} \\
\hline \multirow{2}{*}{ Equation of } & $\begin{array}{c}\Delta \mathrm{H}^{\circ}{ }_{\text {ads }}\left(\mathrm{kJ} \mathrm{mol}^{-1}\right) \\
\text { van't Hoff }\end{array}$ & $\begin{array}{c}\Delta \mathrm{H}^{\circ}{ }_{\text {ads }}\left(\mathrm{kJ} \mathrm{mol}^{-1}\right) \\
\mathrm{Gibbs}^{-1} \text { Helmholtz }\end{array}$ \\
\hline M1 & -31.73 & -31.81 \\
M2 & -29.46 & -29.60 \\
\hline
\end{tabular}

covalent bonds with the metal formed between the unpaired electrons of the $\mathrm{N}$-atom.

Quantum-chemical calculations: The relationship between the molecular. the electronic structure and the inhibition efficiency of the (M1) and (M2) molecules based on density functional theory (DFT) have been investigated. Fig. 10 shows the full geometry optimizations of. bipyrazole derivatives. M1 and M2 using DFT based on Beck's three parameter exchange functional and Lee-Yang-Parr non-local correlation functional (B3LYP) [57-59] and the 6-31G** orbital basis sets for all atoms as implemented in Gaussian 09 program [25].

The quantum chemical parameters of M1 and M2 were calculated and presented in Table-8. Ionization potential (I), electron affinity (A), global hardness $(\eta)$, global electrophilicity index $(\chi)$, softness $(S)$ and back donation energy $\left(\Delta \mathrm{E}_{\text {back donation }}\right)$ were determined as in previous work [29].

\begin{tabular}{lcc}
\multicolumn{4}{c}{ TABLE-8 } \\
CALCULATED QUANTUM CHEMICAL \\
\multicolumn{3}{c}{ PARAMETERS OF THE STUDIED MOLECULES } \\
\hline Quantum chemical parameters & -5.74405361 & -6.055896209 \\
\hline $\mathrm{E}_{\mathrm{HOMO}}(\mathrm{eV})$ & 0.663958066 & -0.809266921 \\
$\mathrm{E}_{\mathrm{LUMO}}(\mathrm{eV})$ & 6.408011675 & 5.246629288 \\
$\Delta \mathrm{E}_{\mathrm{g}}=\mathrm{E}_{\mathrm{LUMO}}-\mathrm{E}_{\mathrm{HOMO}}(\mathrm{eV})$ & 5.74405361 & 6.055896209 \\
$\mathrm{IP}=-\mathrm{E}_{\mathrm{HOMO}}(\mathrm{eV})$ & -0.663958066 & 0.809266921 \\
$\mathrm{EA}=-\mathrm{E}_{\mathrm{LUMO}}(\mathrm{eV})$ & 3.204005838 & 2.623314644 \\
$\eta(\mathrm{eV})$ & 2.7007 & 6.4089 \\
$\mu($ debye $)$ & 1.13822834 & 7.828645203 \\
$\chi$ & 0.312109294 & 0.381197125 \\
$\mathrm{~S}$ & -0.801001459 & -0.655828661 \\
$\Delta \mathrm{E}_{\text {back donation }}$ & & \\
\hline
\end{tabular}

The shape of the HOMO and LUMO is structural dependant as shown in Fig. 11. The electron density of the HOMO location in the inhibitors under study indicates that the pyrazole ring. The oxygen atoms and the non-cyclic nitrogen atom $s p^{3}$
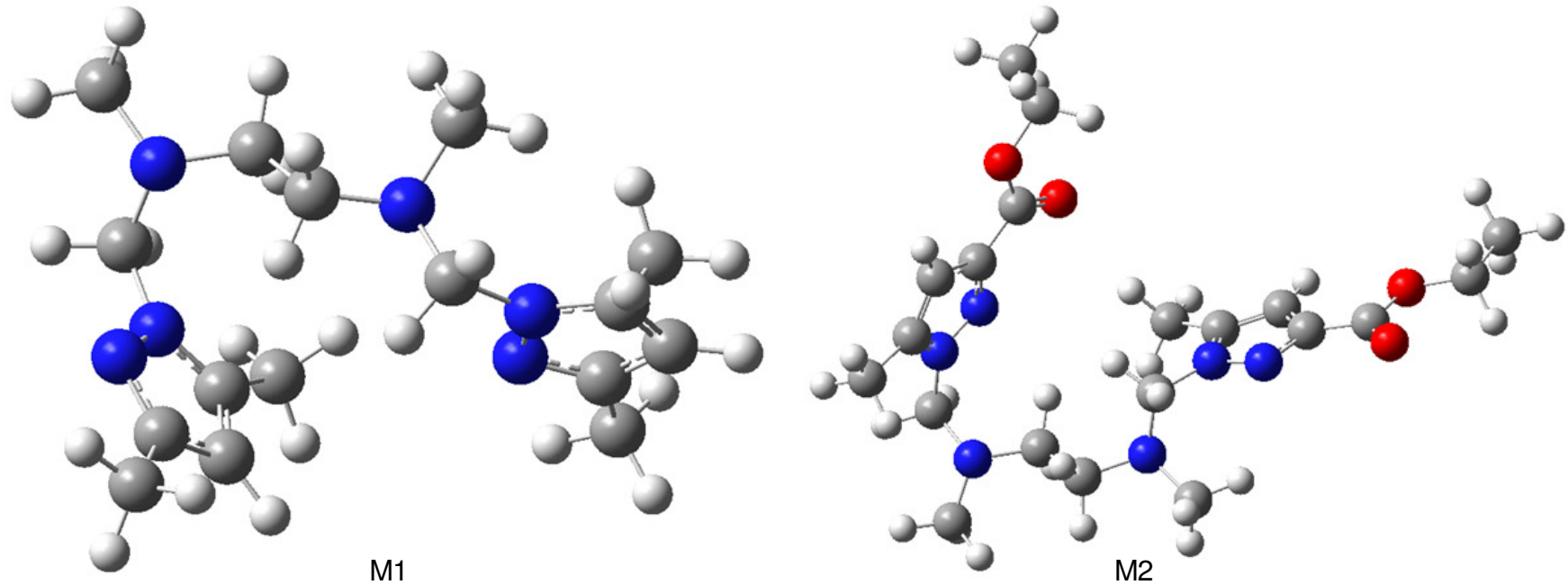

Fig. 10. Optimized structures of the compounds M1 and M2 as calculated at the B3LYP/6-31G** level 


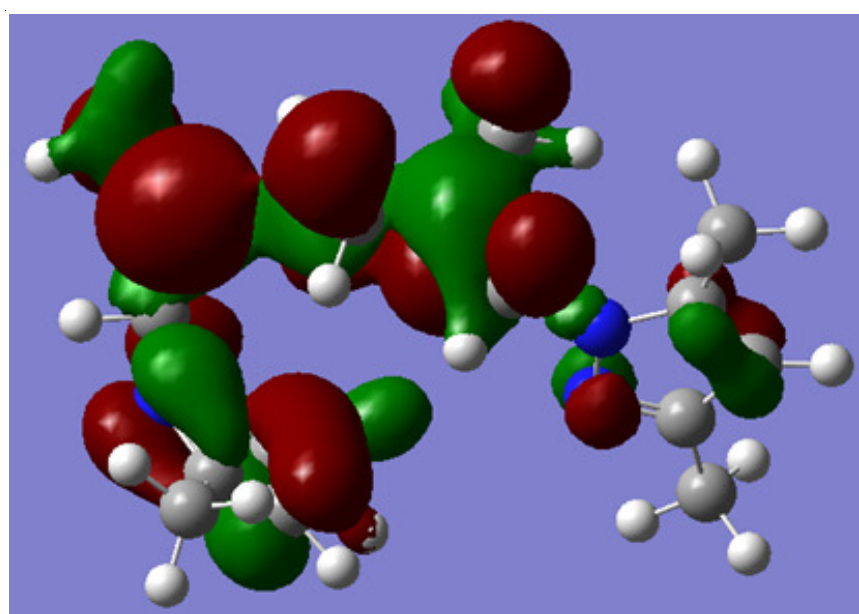

HOMO (M1)

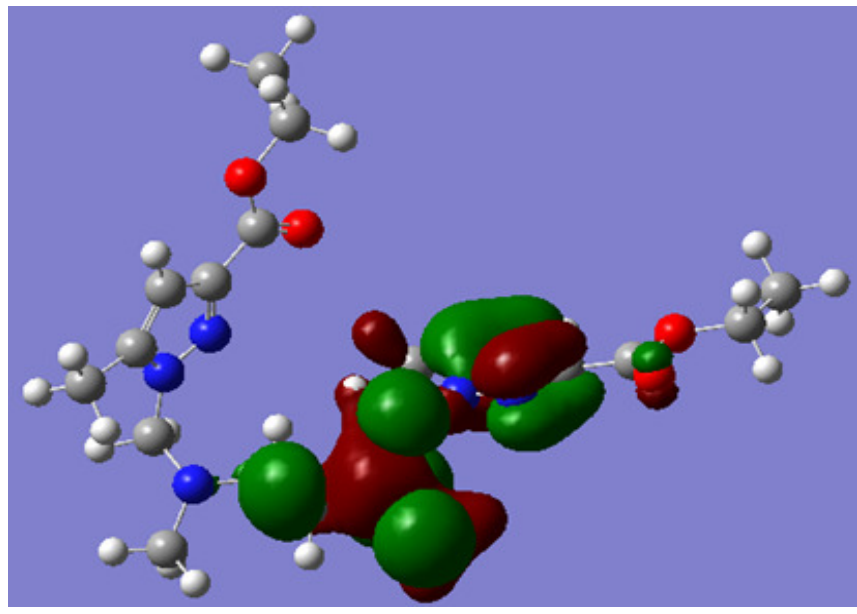

HOMO (M2)

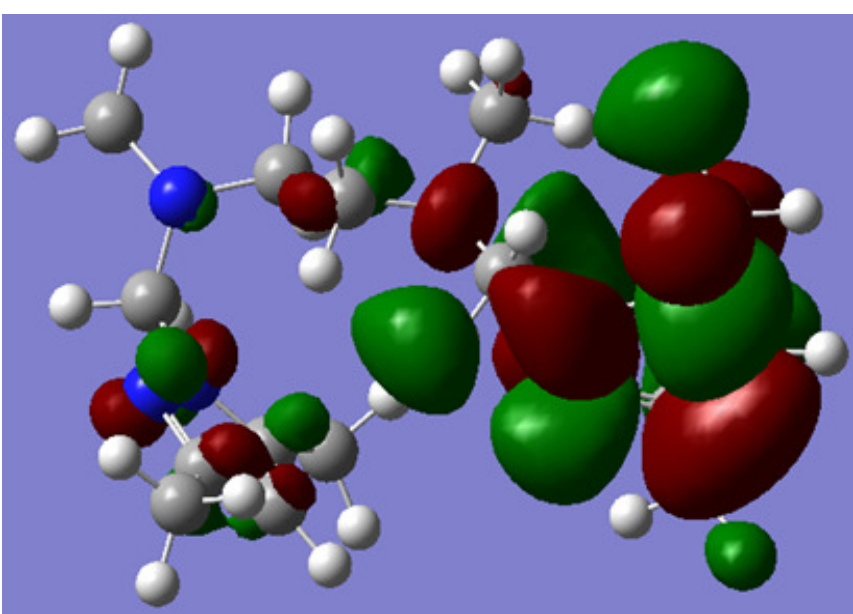

LUMO (M1)

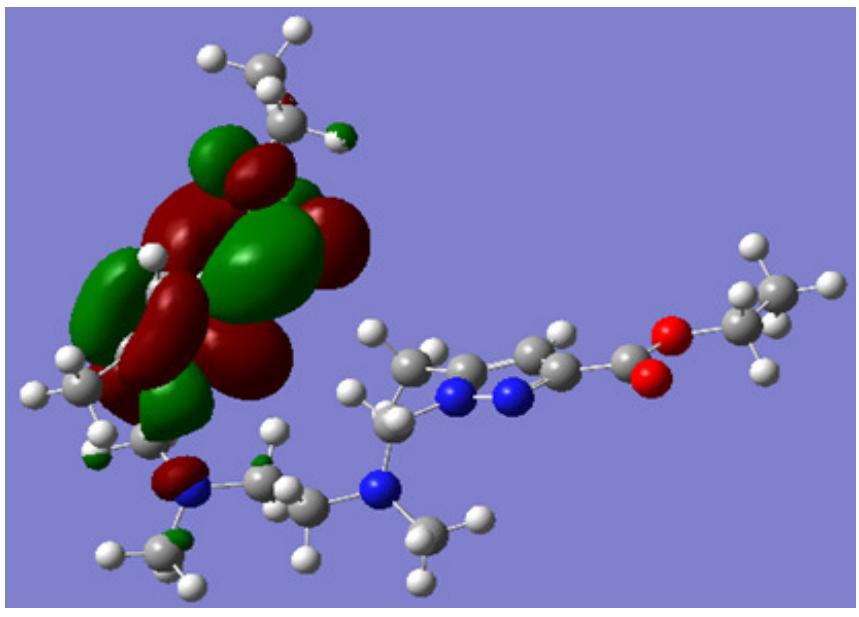

LUMO (M2)

Fig. 11. Schematic representation of HOMO and LUMO molecular orbital of studied molecules

hybridized are the favourite sites for adsorption. This is in good agreement with the literature where the inhibition properties of such compounds were attributed to the interaction between $\pi$-electrons of the pyrazole rings and heteroatoms with the positively charged steel surface $[60,61]$.

Frontier molecular orbital (FMO) theory has revealed that the chemical reactivity includes transition of electron. This is due to interaction between highest occupied molecular orbital (HOMO) and lowest unoccupied molecular orbital (LUMO) of reacting species [62]. So, the inhibitor does not only donate electron to the unoccupied $d$ orbital of the metal ion but of a feedback bond formed by accepting electron from the $d$-orbital of the metal.

In Table- 8 , the trend of energy gap $(\Delta \mathrm{E})$ values follows the order $\mathrm{M} 1>\mathrm{M} 2$. It well known that $\Delta \mathrm{E}$ decreases. The reactivity of the molecule increases leading to increase in the $\%$ IE of the molecule [63]. This interpret the highest reactivity of M2 $(\Delta \mathrm{E}=5.246629288 \mathrm{eV})$ in comparison to M1 compound and would therefore likely interact strongly with the mild steel surface. This result is in good agreement with the mass loss data where the inhibition efficiency (IE) for inhibitor M2 is the higher. The dipole moment $(\mu)$ for compound M2 is about 6.4089 (Debye). This high value of $\mu$ increases the contact area between the M2 molecule and mild steel surface and rise the corrosion inhibition ability of this inhibitors [64]. This also confirmed by hardness $(\eta)$ and softness (S) values in Table- 8 . The inhibitor M2 has the lowest hardness value. 2.623314644 $\mathrm{eV}$ and the highest global softness value (S). $0.381197125 \mathrm{eV}$ when compared with the corresponding values of compound M1, respectively. The absolute hardness and softness are important properties to measure the molecular stability and reactivity. In order to measure the ability of the molecules to accept electrons from other species. The global electrophilicity index, $\chi$ detected, bipyrazole derivative M2 is with high electrophilicity index value (7.828645203) than M1. So that M2 is the strongest nucleophile and therefore has the highest inhibition efficiency. The lower calculated $\Delta \mathrm{E}_{\text {back donation value for }}$ M2 values indicates that back-donation is favoured for this molecule which is the best inhibitor.

The effective atomic charges from Mulliken poupulations of the inhibitors M1 and M2 in Fig. 12 shows that oxygen atoms of ester groups with its powerful mesomer effect which facilitate the delocalization of electrons have as expected the biggest negative charges (around-0.492). This followed by the two nitrogens bearing methyl groups $(-0.421)$ and the nitrogens of pyrazole rings $(-0.344)$. This clarify that these nitrogen atoms are the negative charge centers. These centers can offer electrons to the meta atoms to form coordinate bond. The atoms 

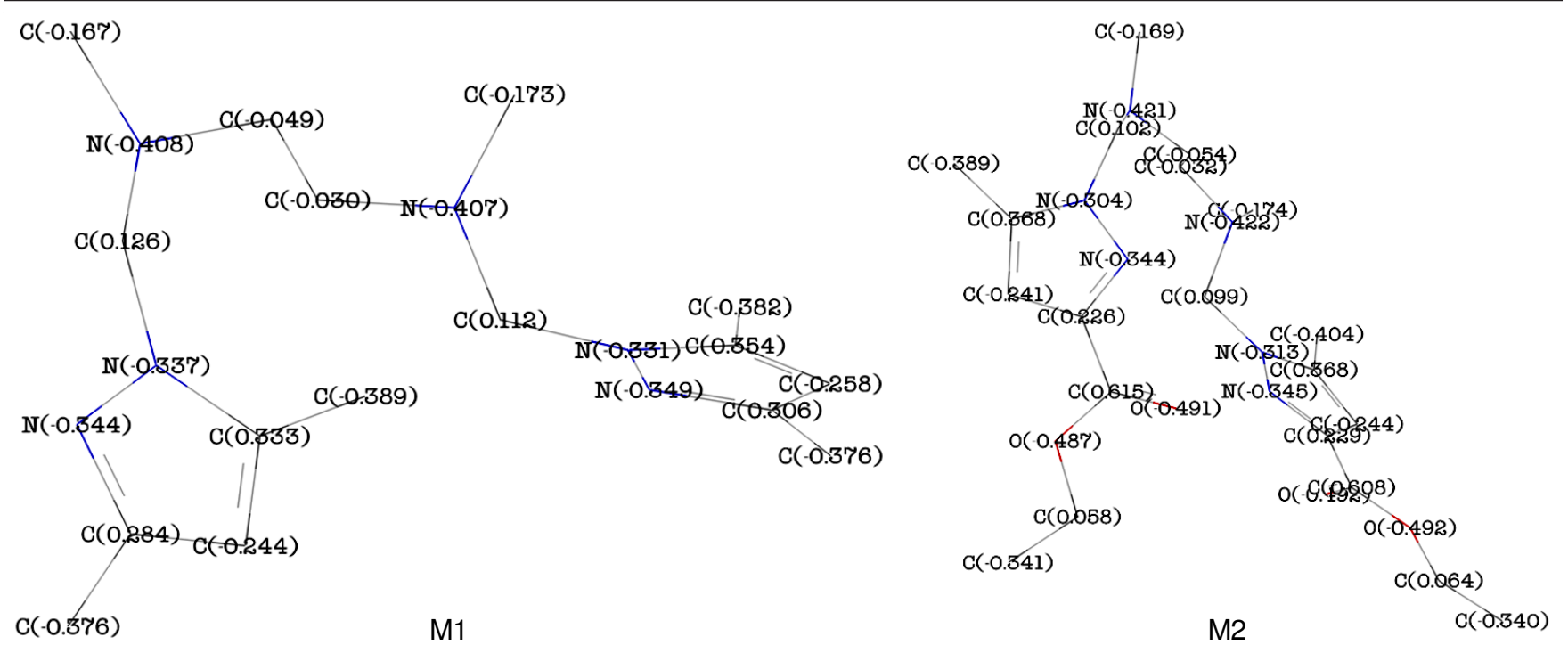

Fig. 12. Effective atomic charges of heavy atoms from Mulliken poupulations of M1 and M2 (hydrogen atoms are not shown for clarity reasons)

that carrying positive charges are the positive charge centers, which can accept electrons from orbital of metal atoms to form feedback bond.

The optimized structure can be inferred the presence of oxygen atoms of ester groups. The two nitrogens bearing methyl groups and the pyrazole rings are the possible active adsorption sites.

Molecular dynamic simulation study-adsorption energy calculations: In the present study, the molecular dynamic (MCs) simulation incorporating molecular mechanics and molecular dynamics can be used to simulate the adsorption for (one of M1/M2 molecule) $/ 30 \mathrm{H}_{2} \mathrm{O} / \mathrm{Fe}$ (111) system. The adsorption of single inhibitor (M1/M2) molecule on the iron (111) surface in water solvent molecules and the formation of the (M1-Fe $e_{\text {ads }} / \mathrm{M} 2-\mathrm{Fe}_{\text {ads }}$ ) organometallic complexes on the iron surface were considered. The system was studied to find the lowest energies adsorption active centers on the inhibitor (M1/ M2) molecules [29,30]. Full geometry optimization of all investigated systems were performed using Materials Studio $\mathrm{DMol}^{3}$ and Adsorption locator version 8.0 [26]. A high quality quantum mechanics computer program [26], the neutral and isolated form of one (M1/M2) molecules configuration are sampled from a canonical ensemble. The $\mathrm{DMol}^{3}$ geometry optimization of the neutral form of M2 molecule before putting it on the iron surface using MCs are presented in Fig. 13.
The adsorption energy distribution for (one of M2 molecule)/Fe (1 11 1)/30 $\mathrm{H}_{2} \mathrm{O}$ system using $\mathrm{MC}_{\mathrm{S}}$ are depicted in Fig. 14.

The total energy, average total energy, van der Waals energy, electrostatic energy and intermolecular energy for (one of M2 molecule)/Fe (1 11 1)/30 $\mathrm{H}_{2} \mathrm{O}$ system were calculated by optimizing the whole system and given in Fig. 15.

The conformation of the most suitable inhibitor (M2) adsorbed onto $\mathrm{Fe}(111)$ surface $\left(30 \mathrm{H}_{2} \mathrm{O}\right)$ in water solvent molecules obtained by the adsorption location module [29,30]. The top (right) and side (left) views of the most stable adsorption configurations for the adsorption of bipyrazole derivatives on iron Fe (111) surface in water solvent molecules obtained by MCs are shown in Fig. 16.

As can be seen in Fig. 4 that the $\pi$-electrons of the pyrazole rings, the oxygen (-O-) atoms and the non-cyclic nitrogen $(-\mathrm{N}=)$ atoms are the favourite actives sites and plays the main role of the adsorption of (M1/M2) molecules with the positively charged iron surface in water solvent molecules. All inhibitor molecules adsorbed nearly plane on the iron (111) surface in water solvent molecules to maximize surface coverage and contact (Fig. 16). This ensures strong interaction and by extension high inhibition effect observed experimentally. The values for the outputs and descriptors obtained from the Monte Carlo simulations are listed in Table-9.

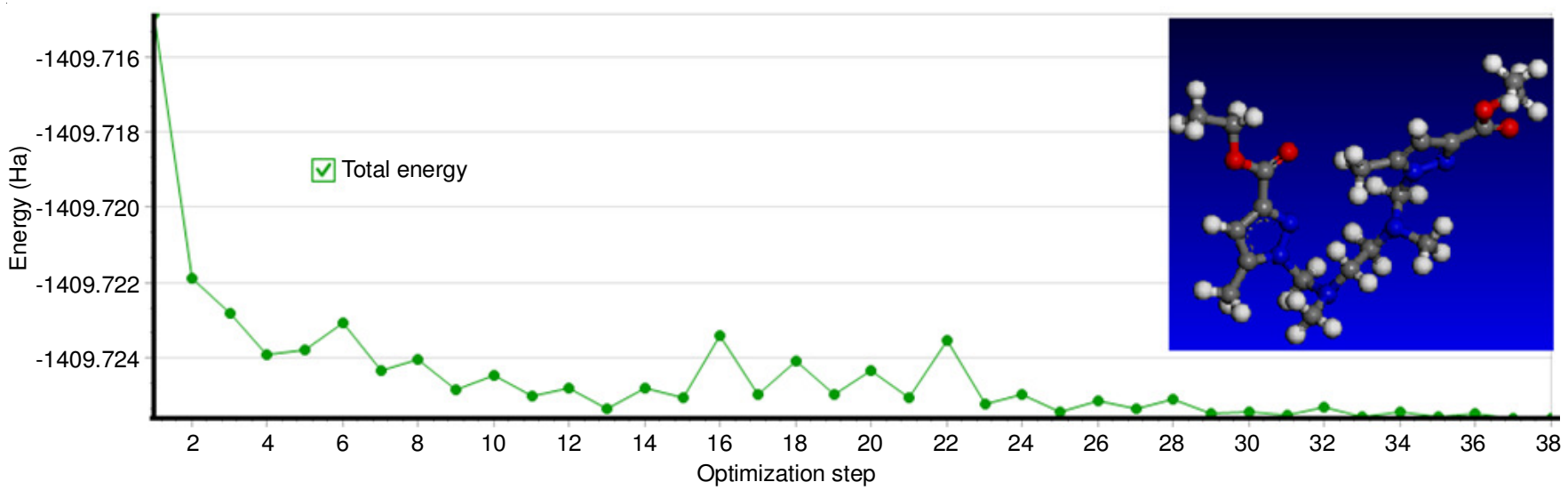

Fig. 13. The $\mathrm{DMol}^{3}$ geometry optimization of $\mathrm{M} 2$ molecule before putting it on the iron surface using MCs 


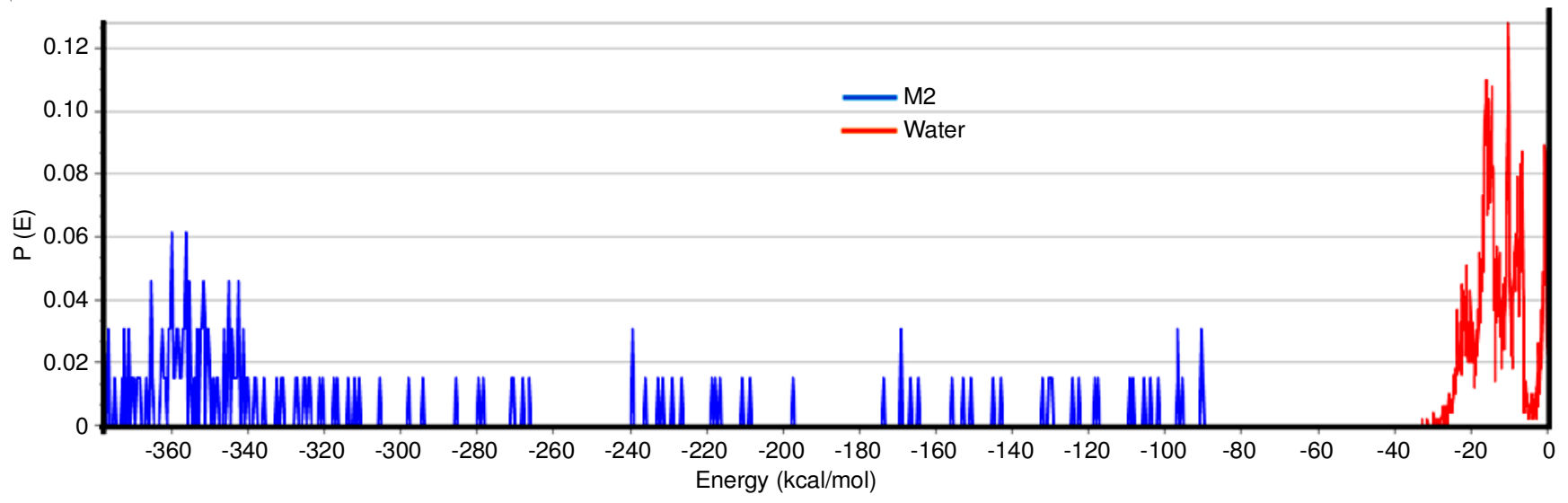

Fig. 14. Adsorption energy distribution for (one of $\mathrm{M} 2$ molecule) $/ 30 \mathrm{H}_{2} \mathrm{O} / \mathrm{Fe}$ (111) system

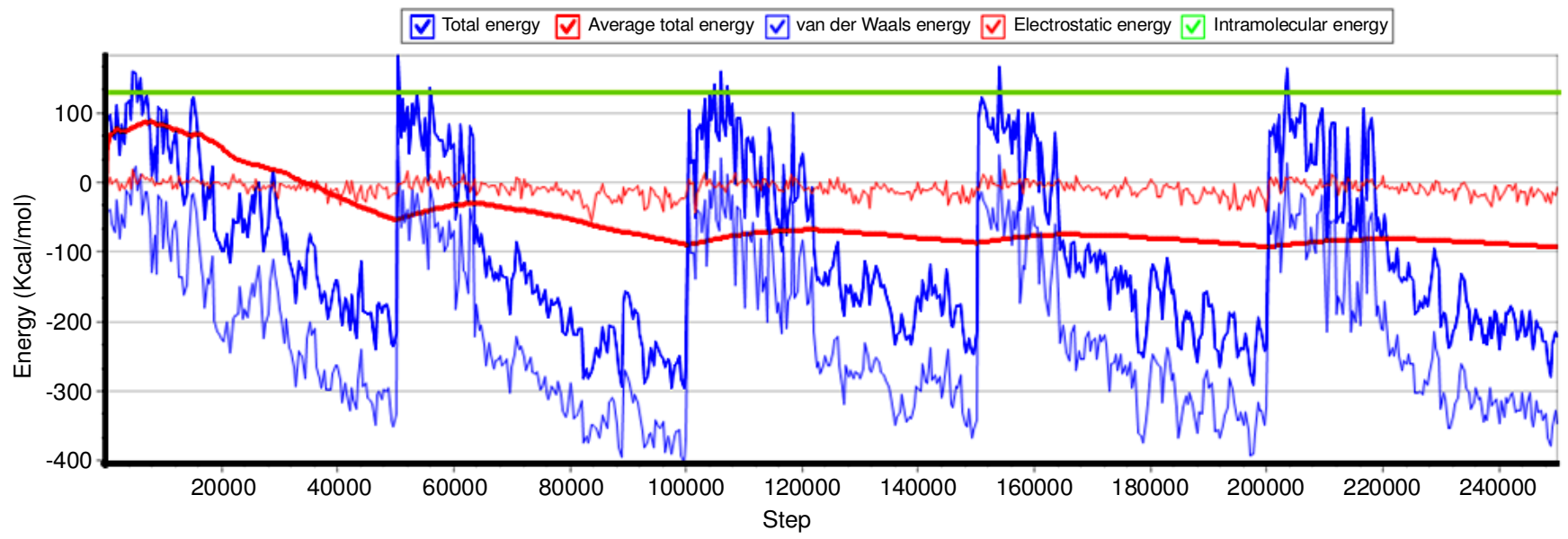

Fig. 15. Total energy distribution for M2/Fe (110) surface in water solvent molecules

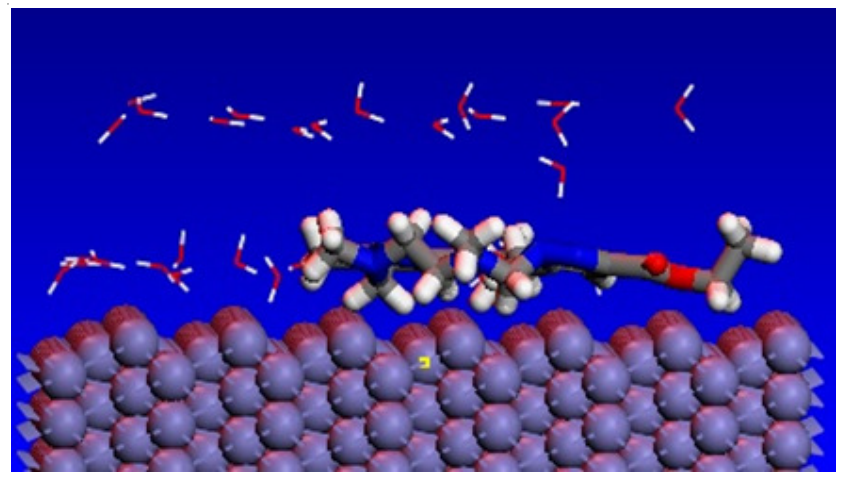

Side (M1)

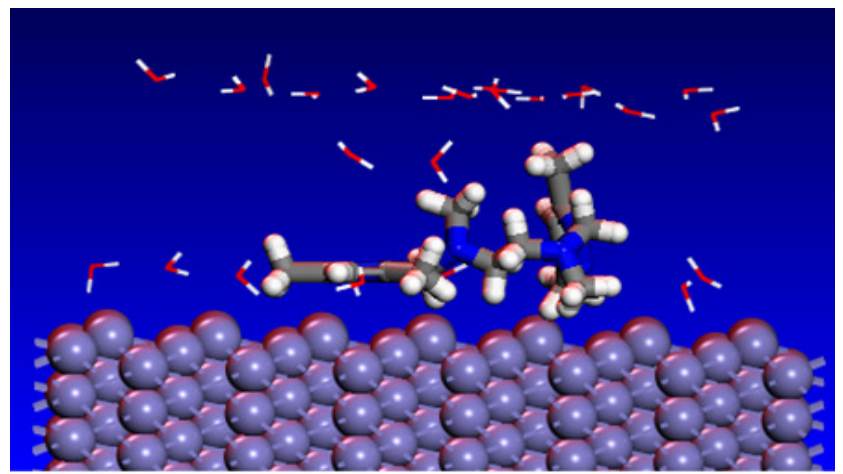

Side (M2)

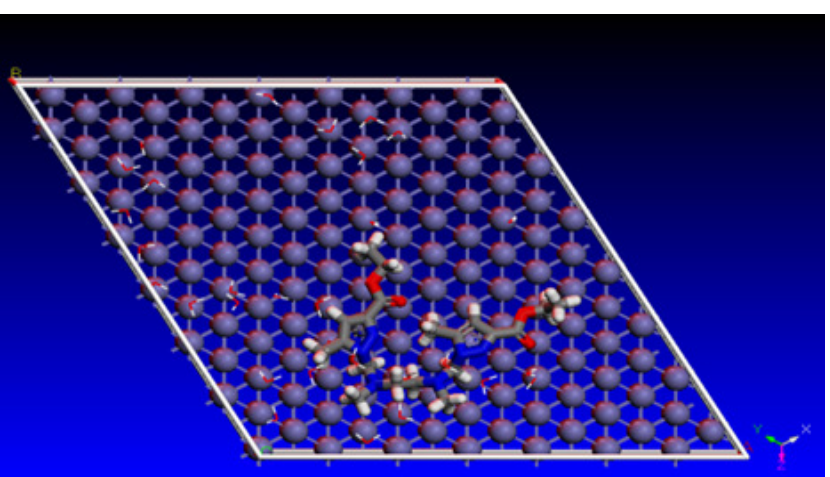

Top (M1)

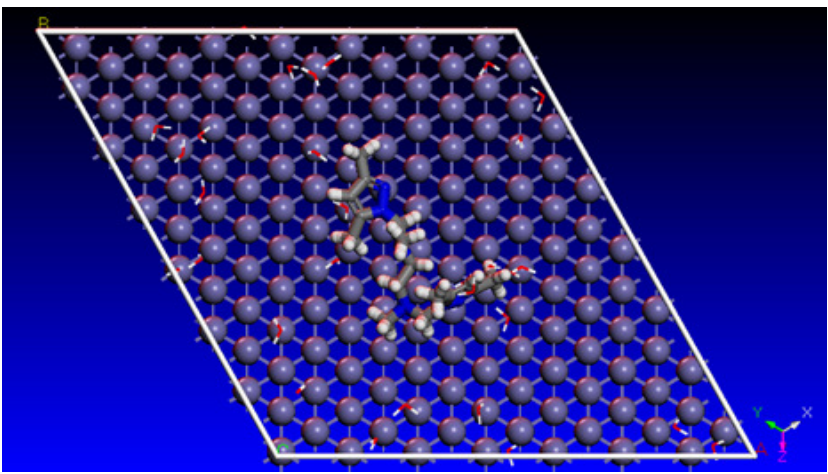

Top (M2)

Fig. 16. Top (right) and side (left) views of the most stable energies configuration for the adsorption of (M1/M2) molecules on iron Fe (111) surface in water solvent molecules obtained by MCs 


\begin{tabular}{|c|c|c|c|c|c|c|}
\hline \multicolumn{7}{|c|}{$\begin{array}{c}\text { TABLE- } 9 \\
\text { OUTPUTS AND DESCRIPTORS VALUES FOR THE MOST STABLE ADSORPTION } \\
\text { CONFIGURATIONS FOR (M1/M2)/Fe }(111) / 30 \mathrm{H}_{2} \mathrm{O} \text { SYSTEM }(\mathrm{Kcal} / \mathrm{mol})\end{array}$} \\
\hline Systems & $\mathrm{E}_{\text {Total }}$ & $\mathrm{E}_{\mathrm{Ads}}$ & R.A.E & $E_{\text {def }}$ & $\mathrm{dE}_{\mathrm{ads}} / \mathrm{dNi} \mathrm{M} 1 / \mathrm{M} 2$ & $\mathrm{dE}_{\mathrm{ads}} / \mathrm{dN}_{\mathrm{i}}$ water \\
\hline $\mathrm{M} 1 / \mathrm{Fe}(111) / 30 \mathrm{H}_{2} \mathrm{O}$ & -543.122 & -552.526 & -556.877 & +4.351 & -172.373 & -9.891 \\
\hline $\mathrm{M} 2 / \mathrm{Fe}(111) / 30 \mathrm{H}_{2} \mathrm{O}$ & -602.033 & -733.093 & -666.930 & -66.163 & -356.66 & -0.412 \\
\hline
\end{tabular}

From the Table-9, the parameters include total energy ( $\mathrm{E}_{\text {Total }}$ ) of the (one of M1/M2 molecules) $/ 30 \mathrm{H}_{2} \mathrm{O} / \mathrm{Fe}$ (111) system. The total energy is defined as the sum of the energy of the inhibitor, the rigid adsorption energy (RAE) and the deformation energy $\left(\mathrm{E}_{\mathrm{def}}\right)$. In addition. adsorption energy $(\mathrm{Kcal} / \mathrm{mol})$, reports energy released when the relaxed inhibitor and some molecules of water (one molecule of inhibitor $/ 30 \mathrm{H}_{2} \mathrm{O}$ ) are adsorbed onto the iron (111) surface. The energy released when the unrelaxed inhibitor molecule (before the geometry optimization step) are adsorbed on the iron (111) surface reported by rigid adsorption energy. The deformation energy reports the energy released when the adsorbed inhibitor molecule is relaxed on the iron surface. Table- 9 shows also $\left(\mathrm{dE}_{\text {ads }} / \mathrm{dN}_{\mathrm{i}}\right)$, which reports the energy $(\mathrm{Kcal} / \mathrm{mol})$ of $\mathrm{Fe}_{\text {ads }}$-inhibitor complexes configuration where one of the inhibitor molecule has been removed.

It is clear from Table-9 that the values of adsorption energies and values of the adsorption systems were -419.515 and $-425.946(\mathrm{kcal} / \mathrm{mol})$ for M1 and M2, respectively. Both values are negative, which denotes that the adsorption could occur spontaneously. The largest negative adsorption energy value indicate the system with the most stable and stronger adsorption $[65,66]$. The adsorption energies of the inhibitors molecules are higher than that of water molecules in all cases. That means the possibility of gradual substitution of water molecules from the iron surface leading in the formation of a stable layer which can protect the iron from aqueous corrosion.

It is obvious that M2 gives more negative adsorption energy which means that adsorption of M2 on iron surface in water solvent molecules is stronger than M1. This result is in good agreement with the experiment where the inhibition efficiency (IE) for inhibitor M2 is the higher.

\section{Conclusions}

The following results can be drawn from this study:

- Bipyrazole derivatives (M1 and M2) are found to act as mixed inhibitors and their protection efficiencies increase with inhibitors concentration.

- The weight loss, dc polarization and ac impedance are in reasonably good agreement.

- The inhibition efficiency (E \%) of M1 and M2 were temperature-dependent and their addition led to a decrease of the activation corrosion energy.

- The thermodynamic parameters show that the protection of corrosion by bipyrazole derivatives is due to the formation of a chemisorbed film on the mild steel surface.

- Adsorption of bipyrazole derivatives was found to follow the Langmuir's adsorption isotherm.

- DFT calculations correlate strongly with experimental results and reveal that the inhibition efficiency grows in the following order: $\mathrm{M} 1<\mathrm{M} 2$.

- It can be concluded that M1 and M2 are good inhibitors for the corrosion of mild steel in $\mathrm{HCl}$ solution. The protection potentials of the inhibitors are due to the transfer of electron from the inhibitor to $\mathrm{Fe}$ in mild steel or vice versa.

- The study emphasized that the oxygen atoms of ester groups, the two nitrogens bearing methyl groups and the pyrazole rings are the possible active adsorption sites. Therefore, the use of quantum chemical parameters is appropriate in modelling the inhibitory of the studied bipyrazole based molecules.

- The simulation suggest that bipyrazole derivatives adsorb on the iron (111) surface in water solvent molecules nearly plane with a high negative adsorption energy, yet M2 has better corrosion inhibition performance than M1. This result is in good agreement with the experiment where the inhibition efficiency (IE) for inhibitor M2 is the higher.

\section{ACKNOWLEDGEMENTS}

One of the authors, Prof. Y. Karzazi extends his appreciation to the Laboratory for Chemistry of Novel Materials, University of Mons, Belgium for access to the computational facility.

\section{REFERENCES}

1. V.S. Sastri, Corrosion Inhibitors-Principles and Applications, Wiley, Chichester, England (1998)

2. I. El-Ouali, B. Hammouti. A. Aouniti. Y. Ramli. M. Azougagh. E.M. Essassi and M. Bouachrine, J. Mater. Environ. Sci., 1, 1 (2010).

3. A. Aouniti, B. Hammouti, M. Brighli, S. Kertit, F. Berhili, S. ElKadiri and A. Ramdani, J. Chim. Phys., 93, 1262 (1996); https://doi.org/10.1051/jcp/1996931262.

4. M. Abdallah and M.M. El-Naggar, Mater. Chem. Phys., 71, 291 (2001); https://doi.org/10.1016/S0254-0584(01)00289-9.

5. M. Elayyachy, M. Elkodadi, A. Aouniti, A. Ramdani, B. Hammouti, F. Malek and A. Elidrissi, Mater. Chem. Phys., 93, 281 (2005); https://doi.org/10.1016/j.matchemphys.2005.03.059.

6. A.G.G. Allah and H. Moustafa, J. Appl. Electrochem., 22, 644 (1992); https://doi.org/10.1007/BF01092613.

7. K. Tebbji, H. Oudda, B. Hammouti, M. Benkaddour, M. ElKodadi, F. Malek and A. Ramdani, Appl. Surf. Sci., 241, 326 (2005); https://doi.org/10.1016/j.apsusc.2004.07.036.

8. F. Touhami, A. Aouniti, Y. Abed, B. Hammouti, S. Kertit, A. Ramdani and K. Elkacemi, Corros. Sci., 42, 929 (2000); https://doi.org/10.1016/S0010-938X(99)00123-7.

9. A. Dafali, B. Hammouti, R. Touzani, S. Kertit, A. Ramdani and K. El Kacemi, Anti-Corros. Methods Mater, 49, 96 (2002); https://doi.org/10.1108/00035590210419335.

10. F. Touhami, B. Hammouti, A. Aouniti and S. Kertit, Ann. Chim. Sci. Mater, 24, 581 (1999); https://doi.org/10.1016/S0151-9107(00)86628-3.

11. A. El-Ouafi, B. Hammouti, H. Oudda, S. Kertit, R. Touzani and A. Ramdani, Anti-Corros. Methods Mater, 49, 199 (2002); https://doi.org/10.1108/00035590210426463.

12. A. Guendouz, B. Ben Cheikhe, N. Boussalah, B. Hammouti, M. Taleb and A. Aouniti, Int. J. Electrochem. Sci., 8, 4305 (2013).

13. M. Elayyachy, M. El Kodadi, B. Hammouti, A. Ramdani and A. Elidrissi, Pigm. Resin Technol., 33, 375 (2004); https://doi.org/10.1108/03699420410568409.

14. F. Bentiss, M. Traisnel, L. Gengembre and M. Lagrenée, Appl. Surf. Sci., 161, 194 (2000); https://doi.org/10.1016/S0169-4332(00)00287-7. 
15. A. Zarrouk, H. Zarrok, R. Salghi, B. Hammouti, R. Touir, I. Warad, F. Bentiss, H. Abou El Makarim and N. Benchat, Res. Chem. Intermed., 39, 1279 (2013); https://doi.org/10.1007/s11164-012-0684-9.

16. M. El-Belghiti, Y. Karzazi, A. Dafali, B. Hammouti, F. Bentiss, I.B. Obot, I. Bahadur and E.E. Ebenso, J. Mol. Liq., 218, 281 (2016); https://doi.org/10.1016/j.molliq.2016.01.076.

17. R. Agrawal and T.K.G. Namboodhiri, J. Appl. Electrochem., 22, 383 (1992); https://doi.org/10.1007/BF01092693.

18. K. Tourabi, K. Nohair, N. Nyassi, B. Hammouti, F. Bentiss and A. Chetouani, Mor. J. Chem., 1, 33 (2013).

19. L. Wang, M.-J. Zhu, F.-C. Yang and C.-W. Gao, Int. J. Corros., Article ID 573964 (2012); https://doi.org/10.1155/2012/573964

20. M. Tourabi, K. Nohair, A. Nyassi, B. Hammouti, C. Jama and F. Bentiss. J. Mater. Environ. Sci., 4, 1133 (2014).

21. S. Kertit and B. Hammouti, Appl. Surf. Sci., 93, 59 (1996); https://doi.org/10.1016/0169-4332(95)00189-1.

22. S. Kertit, H. Es-Soufi, B. Hammouti and M. Benkaddour, J. Chim. Phys., 95, 2070 (1998); https://doi.org/10.1051/jcp:1998355

23. S. Kertit, K. Bekkouche and B. Hammouti, Rev. Métall. (Paris), 95, 251 (1998).

24. Y. Aouine, Int. J. Electrochem. Sci., 7, 5400 (2012).

25. M.J. Frisch, G.W. Trucks, H.B. Schlegel, G.E. Scuseria, M.A. Robb, J.R. Cheeseman, G. Scalmani, V. Barone, B. Mennucci, G.A. Petersson, H. Nakatsuji, M. Caricato, X. Li, H.P. Hratchian, A.F. Izmaylov, J. Bloino, G. Zheng, J.L. Sonnenberg, M. Hada, M. Ehara, K. Toyota, R. Fukuda, J. Hasegawa, M. Ishida, T. Nakajima, Y. Honda, O. Kitao, H. Nakai, T. Vreven, J.A. Montgomery Jr., J.E. Peralta, F. Ogliaro, M. Bearpark, J.J. Heyd, E. Brothers, K.N. Kudin, V.N. Staroverov, R. Kobayashi, J. Normand, K. Raghavachari, A. Rendell, J.C. Burant, S.S. Iyengar, J. Tomasi, M. Cossi, N. Rega, J.M. Millam, M. Klene, J.E. Knox, J.B. Cross, V. Bakken, C. Adamo, J. Jaramillo, R. Gomperts, R.E. Stratmann, O. Yazyev, A.J. Austin, R. Cammi, C. Pomelli, J.W. Ochterski, R.L. Martin, K. Morokuma, V.G. Zakrzewski, G.A. Voth, P. Salvador, J.J. Dannenberg, S. Dapprich, A.D. Daniels, Ö. Farkas, J.B. Foresman, J.V. Ortiz, J. Cioslowski and D.J. Fox, Gaussian Inc., Wallingford CT (2009).

26. Materials Studio version 8.0. Accelrys Inc. USA (2014).

27. K. Stueckenschneider, J. Merz, V. Milman and G. Schembecker, J. Cheminformatics, 5S1, O11 (2013); https://doi.org/10.1186/1758-2946-5-S1-O11

28. H. Sun, Polyp. Sci., 8, 229 (1998).

29. M.E. Belghiti, Y. Karzazi, A. Dafali, I.B. Obot, E.E. Ebenso, K.M. Emran, I. Bahadur, B. Hammouti and F. Bentiss, J. Mol. Liq., 216, 874 (2016); https://doi.org/10.1016/j.molliq.2015.12.093.

30. L. Guo, S. Zhu, S. Zhang, Q. He and W. Li, Corros. Sci., 87, 366 (2014); https://doi.org/10.1016/j.corsci.2014.06.040.

31. M. Bouklah, A. Attayibat, S. Kertit, A. Ramdani and B. Hammouti, Appl. Surf. Sci., 242, 399 (2005); https://doi.org/10.1016/j.apsusc.2004.09.005.

32. K. Tebbji, I. Bouabdellah, A. Aouniti, B. Hammouti, H. Oudda, M. Benkaddour and A. Ramdani, Mater. Lett., 61, 799 (2007); https://doi.org/10.1016/i.matlet.2006.05.063.

33. S.S.A. El-Rehim, M.A.M. Ibrahim and K.F. Khaled, J. Appl. Electrochem., 29, 593 (1999); https://doi.org/10.1023/A:1003450818083.

34. M. Bouklah, A. Ouassini, B. Hammouti and A.E. Idrissi, Appl. Surf. Sci., 250, 50 (2005); https://doi.org/10.1016/j.apsusc.2004.12.021

35. I.L. Rosenfeld, Corrosion Inhibitors, McGraw-Hill. New York (1981).

36. T. Murakawa, S. Nagaura and N. Hackerman, Corros. Sci., 7, 79 (1967); https://doi.org/10.1016/S0010-938X(67)80105-7.

37. N. Hackerman, E.S. Snavely and J.S. Payne, J. Electrochem. Soc., 113, 677 (1966); https://doi.org/10.1149/1.2424089.

38. H. Ashassi-Sorkhabi, B. Shaabani and D. Seifzadeh, Electrochim. Acta, 50, 3446 (2005); https://doi.org/10.1016/i.electacta.2004.12.019.
39. K.F. Khaled, Appl. Surf. Sci., 230, 307 (2004); https://doi.org/10.1016/j.apsusc.2004.02.041.

40. K.F. Khaled, Appl. Surf. Sci., 252, 4120 (2006) https://doi.org/10.1016/j.apsusc.2005.06.016.

41. E. McCafferty and N. Hackerman, J. Electrochem. Soc., 119, 146 (1972); https://doi.org/10.1149/1.2404150.

42. A. Popova, Corros. Sci., 49, 2144 (2007); https://doi.org/10.1016/j.corsci.2006.10.020.

43. G.N. Mu, X. Li and F. Li, Mater. Chem. Phys., 86, 59 (2004); https://doi.org/10.1016/j.matchemphys.2004.01.041.

44. A. Yurt, A. Balaban, S.U. Kandemir, G. Bereket and B. Erk, Mater. Chem. Phys., 85, 420 (2004);

https://doi.org/10.1016/j.matchemphys.2004.01.033.

45. T. Tsuru, S. Haruyama and B. Gijutsu, Jpn. Soc. Corros. Eng., 27, 573 (1978).

46. A.E.-A.S. Fouda, H.A. Mostafa and H.M. Abu-Elnader, Monatsh. Chem., 120, 501 (1989); https://doi.org/10.1007/BF00810836.

47. M. Bouklah, N. Benchat, B. Hammouti, A. Aouniti and S. Kertit, Mater. Lett., 60, 1901 (2006); https://doi.org/10.1016/j.matlet.2005.12.051.

48. M. Bouklah, B. Hammouti, M. Benkaddour, A. Attayibat and S. Radi, Pigm. Resin Technol., 34, 197 (2005); https://doi.org/10.1108/03699420510609088.

49. M. Bouklah, B. Hammouti, M. Benkaddour and T. Benhadda, J. Appl. Electrochem., 35, 1095 (2005); https://doi.org/10.1007/s10800-005-9004-Z.

50. F.M. Donahue and K. Nobe, J. Electrochem. Soc., 112, 886 (1965); https://doi.org/10.1149/1.2423723.

51. E. Khamis, F. Bellucci, R.M. Latanision and E.S.H. El-Ashry, Corrosion, 47, 677 (1991); https://doi.org/10.5006/1.3585307.

52. M. Metikos-Hukovic, R. Babic, Z. Grubae and S. Brinic, J. Appl. Electrochem., 26, 443 (1996); https://doi.org/10.1007/BF00251331.

53. H.L. Wang, H.-B. Fan and J.-S. Zheng, Mater. Chem. Phys., 77, 655 (2003); https://doi.org/10.1016/S0254-0584(02)00123-2.

54. F.M. Bayoumi and W.A. Ghanem, Mater. Lett., 59, 3806 (2005); https://doi.org/10.1016/j.matlet.2005.06.070.

55. S. Tu, X. Jiang, L. Zhou, M. duan, H. Wang and X. Jiang, Corros. Sci., 65, $13(2012)$ https://doi.org/10.1016/j.corsci.2012.07.022

56. M.P. Soriaga, Chem. Rev, 90, 771 (1990); https://doi.org/10.1021/cr00103a006.

57. A.D. Becke, J. Chem. Phys., 97, 9173 (1992); https://doi.org/10.1063/1.463343.

58. A.D. Becke, J. Chem. Phys., 98, 1372 (1993); https://doi.org/10.1063/1.464304

59. C. Lee, W. Yang and R.G. Parr, Phys. Rev. B, 37, 785 (1988); https://doi.org/10.1103/PhysRevB.37.785.

60. M.A. Amin, K.F. Khaled and S.A. Fadl-Allah, Corros. Sci., 52, 140 (2010); https://doi.org/10.1016/j.corsci.2009.08.055.

61. H. Wang, X. Wang, H. Wang, L. Wang and A. Liu, J. Mol. Model., 13, 147 (2006); https://doi.org/10.1007/s00894-006-0135-X.

62. P. Zhao, Q. Liang and Y. Li, Appl. Surf. Sci., 252, 1596 (2005); https://doi.org/10.1016/j.apsusc.2005.02.121.

63. I.B. Obot, N.O. Obi-Egbedi and S.A. Umoren, Int. J. Electrochem. Sci., 4, 863 (2009).

64. X. Li, S. Deng, H. Fu and T. Li, Electrochim. Acta, 54, 4089 (2009); https://doi.org/10.1016/j.electacta.2009.02.084.

65. A.M. Kumar, R. Suresh Babu, I.B. Obot and Z.M. Gasem, RSC Adv., 5, 19264 (2015); https://doi.org/10.1039/C4RA13470B

66. I.B. Obot, S.A. Umoren, Z.M. Gasem, R. Suleiman and B.E. Ali, J. Ind. Eng. Chem., 21, 1328 (2015); https://doi.org/10.1016/j.jiec.2014.05.049. 